\title{
How Flexible Work Arrangements Affects Affective Organizational Commitment, and Work-Life Enrichment in Pakistan's Service Industry: The Role of Time Planning, Work-Life Conflict, and Engagement
}

\author{
Alpha Kaleb Gill (Corresponding author) \\ Karachi University Business School, \\ University of Karachi, Pakistan \\ E-mail: alphagil195@gmail.com \\ Danish Siddiqui \\ Karachi University Business School, \\ University of Karachi, Pakistan \\ E-mail: daanish79@hotmail.com
}

Received: April 23, 2020 Accepted: October 10, 2020 Published: November 10, 2020

doi: 10.5296/hrr.v4i1.16894 URL: https://doi.org/10.5296/hrr.v4i1.16894

\begin{abstract}
Work-life balance is now being encouraged in organizations across different cultures. Moreover, amidst the current 'pandemic' status of widespread disease COVID-19, its essential for businesses to operate remotely as FWAs response to these challenges. The purpose is to focus on explaining how FWAs induce affective commitment as well as help in achieving work-life enrichment. For this, we proposed a theoretical framework hypothesizing that FWAs reduce work-life conflicts as well as make employees more engaged. The effect of FWAs on these two is also complemented by better time planning. Reduction of conflicts and enhanced engagement would, in turn, increase affective organizational commitment and work-life enrichment. Empirical significance was calculated by performing a survey using a questionnaire to collect data from 300 service sector employees in Pakistan. We determined our results by using structural equation modeling. The results suggested that FWAs are significantly and positively related to affective organizational commitment, engagement, and
\end{abstract}


work-life enrichment, whereas negatively and significantly affect work-life conflict. Moreover, engagement also positively affects enrichment and affective commitment. Surprisingly, work-life conflict seems to positively affect work-life enrichment. Time planning seems to negatively complement the effect of FWAs on work-life conflict whereas, positively affect engagement. This study concludes that positive outcomes are generated by simply providing FWAs and more friendly policies whereby increasing effectiveness and ensuring business success continuity.

Keywords: Flexible Working Arrangements (FWA), Affective Organizational Commitment (AOC), Employee Engagement (EE), Work-life Conflict (WLC), Work-life Enrichment (WLE), Time planning behavior (TPB), Karachi, Pakistan

\section{Introduction}

\subsection{Background}

Flexible arrangement practices have become common in numerous organizations as part of a core strategy to recruit, inspire and retain key skilled workers (Hill et al., 2008) (Society of human resource management, 2010). It helps organizations to meet the changing needs of the workplace by offering work-time flexibility which leads to reduction in work-life conflicts alleviating stressful work conditions (Allen, Johnson, Kiburz, \& Shockley, 2013). Amidst the current 'pandemic' status of widespread disease COVID-19, as declared by the World Health Organization (WHO) it becomes essential for businesses to operate remotely as many have started to. Global organizations like Unilever, Google, Microsoft, Apple and Nestle' among numerous others have adopted a compulsory home-based program (Lufkin, 2020). World Health Organization reported on mental health and psychosocial issues during the epidemic of COVID-19, which was released on 18 March 2020 suggests using FWAs is the last resort with partnering inexperienced workers with their more experienced colleagues and ensuring a good quality communication, organizations can perform their businesses effectively, without endangering anyone's health or life from impact of corona virus. Flexible workers can become more mindful of the effect of their working conditions on their health, jobs and career growth, eventually leading to empowerment in the form of active self-care and a demand for labour rights (Spurk \& Straub, 2020).

Since late 1980s, many organizations have actively promoted flexible working arrangements including flexible hours and work days, remote working and providing full control of beginning and ending their schedules. Flexibility stood as a revolutionary observation pre-dating industrialization period, where most workers were peasants and were setting their own job schedules (Ronen, 1981). A trend that originated in the USA as a means of versatility in working hours and work schedules and has now become globally acceptable. Flexible employment requires adjustments to the pace and place of work, to cater to the needs of both the manager and the individual (Truss, Mankin, \& Kelliher, 2012). Nature of work has changed from the perspectives of both employees and employer (Heerwagen, 2010) and this change is seen in terms of organizations starting to offer FWAs to employees (Azar, Khan, \& Eerde, 2018) for increasing flexibility and responsiveness as these are becoming two vital strands of organizational strategy when it comes to manage uncertain business environment, 


\section{$\Lambda$ Macrothink}

for example: fixed cost incurred by office space as of today work is geographically dispersed with the help of technology it no longer is tied to any locality or place. The imperative to improve business performance makes flexible working a significant strategic option as it provides desirable benefits to employees enabling them to work at home and at times that suit their personal needs. The usage of flexible work arrangements is motivated by demographic patterns and changes in legislation. Recent regulatory changes in Europe have encouraged companies to provide more flexible working arrangements (Chandola, Booker, Kumari, \& Benzeval, 2019), Pakistan being home to various Multinational Companies is still in its early stages to adopt family supportive policies as there is no such regulation imposed by the government.

Cennamo and Gardner (2008) suggest Generation Y (born in 1980's onwards) i.e. millennials value freedom-related items more than Generation X (1962-79) or Baby boomers (1946-61) thus, their findings support the stereotypical view of Generation $\mathrm{Y}$ as valuing autonomy and work-life balance, as they are known for switching job every now and then (Choo, Desa, \& Asaari, 2016). Theories show that, Millennials are not as loyal as Baby boomers, who prefer to be dedicated for an extensive period of time (Mello, 2019), as millennials become a part of today's workforce its challenging for Pakistani organizations to retain them thus, promoting usage of FWAs shows that they care and are invested in the future of their employees. It is important to note that some studies have found differences in work values between generations, while others have found mixed results (Parry \& Urwin, 2011), but many do agree that each generation is influenced by the times, technology and culture in which they grew up.

Using the lens of social exchange theory (SET) signifies if workers are treated well by their employers the assumption arises that this behaviour would be exchanged by a high degree of performance efficiency and commitment by the employees (Blau, 1964) (Cropanzano, Anthony, Daniels, \& Hall, 2017). We can see that by providing FWAs organizations aim at improving the well-being of workers by adding more balance into their work and life priorities which makes them value and become emotionally attached to the organization as it improves their commitment towards their organization therefore FWAs are ever more becoming part of the strategy of organizations especially when it comes to retaining of talented employees (Kaufman, 2010). Companies should achieve a reasonable degree of allegiance, engagement and job efficiency by exploiting the philosophy of social exchange. Our research builds on this philosophy to better explain how organizations and workers reciprocate through their interaction. Thus, employees who earn economic or social incentives from their employers may therefore be more obligated (Saks, 2006). Likewise, the breach is expected to lead to disengagement and other negative effects (Gould-Williams, 2007). There have been very few studies in Pakistan using this viewpoint so far, so there is little evidence. This theory is used to evaluate the commitment levels of individuals.

We contribute to the existing literature on linkages between FWAs, EE, WLC, WLE, AOC and time planning as we continue to study, how engaging in job and family relationships may have beneficial impacts on the development of personal life, but if workers are unable to fulfill their duties, work-life tension would escalate (Dettmers, Bamberg, \& Seffzek, 2016), 


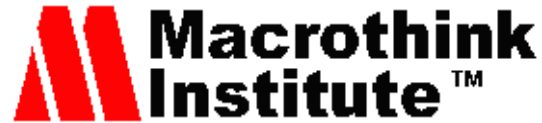

which is associated with increased psychological distress and work-related stress/burnout, high attrition rates, unstable health and performance, low job satisfaction, reduced commitment, increased parental conflict leading to marital distress and poor parenting styles (Aboobaker \& Edward, 2017). It is believed that people prefer to resist stressful conditions and are attracted to positive experiences/events. Such basic norms point to the possibility that people will aspire to create a balance between work and family responsibilities. Uncertain economic climate in Pakistan is a huge obstacle for workers to keep performing well, so we considered the variables that have a beneficial effect on employee morale in order to improve productivity and related evidence indicates that a high degree of dedication contributes to optimal profitability, low absenteeism, higher output and higher production levels, making engagement a valuable factor.

In many emerging and developing South and East Asian economies, strong economic growth has occurred (Budhwar, Varma, \& Patel, 2016). For example, we have witnessed the transformation of China into a capitalist market economy and the liberalization of the Indian economy. Such developments have resulted in a much higher demand for jobs in Asia (Chandra, 2012), a blurring of boundaries between work and home, and a greater emphasis on work-life problems than in the past as its studied that Asians work more hours, being socially acceptable by them than their counterparts in the west (Le, Newman, Menzies, Zheng, $\&$ Fermelis, 2020). Individuals from more polychronic societies tend to do many tasks at once and do not use conventional planning. Cultures that predominate in polychronic culture can have trouble operating under flex time (Masuda, et al., 2012). In general, American countries may have polychronic culture than Asian ones. This research investigates the effects of FWA use and planning on employee outcomes in collectivistic culture like Pakistan which will help the prevailing and future organizations to understand the market for the development of effective family-friendly policies. It will also provide an insight on developing strategies to make the workplace a better place to work. HR initiatives addressing work-life enrichment will be a source of workplace value proposition which could provide companies with a strategic advantage in the employer branding domain in the long run to become the employer of choice.

\subsection{Gap Analysis}

Research in western context has shown benefits accruing from flexible work arrangements usage, such as positive impacts on organizational commitment, and employee performance (Cranfield School of Management, 2008). Impact of FWAs on employee attitudes, work-life conflict and employee turnover intentions were also examined (Allen, Johnson, Kiburz, \& Shockley, 2013) (Galea, Houkes, \& De Rijk, 2014). Across Asia, there have been comparatively fewer FWA studies compared to the US and Europe. Research has largely employed western samples (Masuda, et al., 2012); developing countries have been disregarded except for a couple of late examinations (Dancaster \& Baird, 2016) (Vyas, Lee, \& Chou, 2017) (Chen, Zhang, Sanders, \& Xu, 2016). For example: Ugargol and Patrick (2018) studied the relationship of workplace flexibility encouraging employee engagement in India. (Choo, Desa, \& Asaari, 2016) examine the relationship among flexible working, organizational commitment and work-family conflict in Malaysia showing the relationship's 


\section{Macrothink}

significant. (Michel, Daniel, \& Eduardo, 2015) studied work schedule flexibility with moderating effect on the relationship between enrichment and satisfaction in Bolivia.

Evidence of the existence and use of FWAs in Pakistani organizations is scant. To counter that, Azar et. Al (2018) examined the effect of FWAs on the withdrawal intentions of service sector workers in Pakistan, with the mediating role of job satisfaction and work-life conflict. Planning actions, an aspect of time management, was used to balance the impact of the use of FWAs on reducing work-life tension. We modified Azar et. al. (2018) model, by including crucial mediator like Employee Engagement, as well as instead of studying negative outcomes like turnover intentions, we focused on positive side like Affective Organizational commitment, and Work-life Enrichment following Azar et. al. (2018) call of research making our research first one in the world to examine these linkages. We proposed a theoretical framework hypothesizing that FWAs reduces work life conflicts as well as make employees more engaged. The effect of FWAs on these two are also complemented by better planning. Engaged workforce prioritizing its responsibilities would lead to reduction in work-life conflicts and in turn enrich their work-life and increase commitment.

\subsection{Research Significance}

This paper explores the ties between the flexible work arrangements, affective organizational commitment, employee engagement, work-life conflict and enrichment with complementary role of planning behavior for the very first time. The aim is to aid employees' representatives of service industry which are more vulnerable and susceptible to exhaustion and distress by encouraging management for designing family-friendly working environment as such practices are still very new and uncommon in Pakistan. These connections are clarified with the assistance of SET theory.

Our findings will provide unique orientations to businesses enabling them to capitalize on human resource effectively. Indication of availability/use of FWAs in Pakistani organizations are seldom but this idea of FWAs is not a new one in theory yet it is new when it comes to practicality. Although the relationship between FWA usage and organizational commitment has been studied in Malaysian (2016) context but this component lacks study in Pakistani context. This paper also adds to the current literature on the linkage of FWAs and employee engagement through moderation effect of planning. Our study emphasizes only on one type of organizational commitment i.e. affective organizational commitment which is an individual's desire to stay employed with the organization out of emotional attachment (Meyer \& Allen, 1997) (Meyer \& Herscovitch, 2001). Thus, we focus more on attitudes and emotions of employees linking them to organizational commitment. Growing number of studies on Work-life Enrichment over the years is conducted predominantly in the Western context with minimal representation of other sociocultural contexts (Haar \& Bardoel, 2008) (Chan, et al., 2016) therefore, this paper focuses on studying this variable for the first time in Pakistani context. We claim that to the best of our knowledge it is the first study ever conducted to examine FWAs impact on the positive side by linking it with enrichments and linking time management with Employee Engagement establishing a major contribution by testing the model for the very first time. 


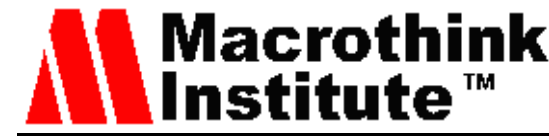

Flexible job conditions can improve the workers' capacity to overcome strain by enhancing commitment, development and emotional participation. A Gallup survey demonstrated the benefits of flexible working arrangements including flextime and remote working opportunities it increases employee's wellbeing, employee engagement and enrich their work life beyond imagination. However, if employees feel their wellbeing is being compromised it discourages their commitment and increases voluntary turnover as their loyalty decreases towards the organization. According to one study carried out by "The American Policy Center" replacement of one employee costs about $20 \%$ of an employee's income (Seppälä \& Cameron, 2015). Therefore, besides being costly its significant to retain talent in this era of knowledge workers where key knowledge resides in the minds of people especially in parts of world like Pakistan which cannot afford to suffers any more from brain drain as majority of our skilled workers get attracted to gulf countries. This line of research will provide much-needed insight into resolving problems related to increasing attrition rate due to brain drain in Pakistan by incorporating family friendly policies to increase commitment.

Throughout the COVID-19 pandemic, several companies responded with limitations on work from home which generated the need for updated and changed HRM policies and procedures for employee performance and assessment and training (Cooke, Schuler, \& Varma, 2020). The findings might be useful for HR managers and policy makers so that they try to contemplate different FWA strategies demonstrating organizational care for well-being and support of its employees and in return gaining commitment from them. It is imperative that today's corporate executives become aware of the promising effects and efficacy of the use of FWAs.

This paper is structured as follows. First, we have literature review and theoretical background to our assumptions. Later, we explain the data, the methods and the software that we are using.

\section{Literature Review}

\subsection{Flexible Working Arrangement (FWA)}

Flexible work comprises of teleworking, remote working and scheduling hours to support employees with balancing work-life domains (De Menezes \& Kelliher, 2017). FWAs are mainly, based on when, where, quantity and continuity of employment (Parkes \& Langford, 2008). (Alis, 2006) made a distinction by analyzing that organizations look for flexibility in ways they can utilize human resources to match supply efficiently with the labour needs thoroughly while operating in an increasingly competitive business environment. However, Individuals look for flexibility in ways they work to reach an adequate balance for work and personal involvement of actions (Truss, Mankin, \& Kelliher, 2012). Balance must be obtained while creating flexibility for employees (Kelliher, Richardson, \& Boiarintseva, 2019). By careful management of FWAs resentment can be avoided among co-workers who get burdened by workload situations because of lesser contribution from their colleagues (Teasdale, 2013). Conferring to Thomas and Ganster (1995), lower WLC is certainly associated with work flexibility along with supportive role of supervisors and impact results for individuals and organization as a whole reducing anxiety and strain (Lapierre \& Allen, 
2006) (Madsen S., 2006). FWA are in greatly claimed by women, dual-earning parents, single-parents and those with geriatric care responsibilities.

\subsection{Affective Organizational Commitment (AOC)}

Earlier researches define organizational commitment as, "A strong belief in and acceptance of the organization's goals and values, with the willingness to employ considerable effort on behalf of the organization and have a strong desire to remain in the organization" (Porter, Mowday, \& Steers, 1979). Meyer and Allen refined distinct mechanisms of organizational commitment known as "Affective, Continuance and Normative Commitment" (Meyer \& Allen, 1991), which address shared concerns of many employers namely absenteeism and turnover etc. AOC is persistently the utmost desired component (Meyer, Stanley, Herscovitch, \& Topolnytsky, 2002). AOC is an employee's emotional attachment to, identification with, trust and involvement in the organization (Kim, Eisenberger, \& Baik, 2016), which largely comes at play in researches (Lambert, Bingham, \& Zabinski, 2020). Its known through researches that staff will develop affective commitment when there exists a collective goal (Ketchand \& Strawser, 2001). Affective commitment is established when employees become fully dedicated by providing continuous provision to accomplish value for organization (Meyer \& Herscovitch, 2001). According to Meyer and Allen, affective commitment refers to, "An individual's desire to be employed with that organization out of his or her emotional attachment."

\subsection{Work-Life Conflict (WLC)}

Conflict arises when demands of a certain role either work or family, utilize finite resources (such as time and energy) that an individual requires to meet the demands of another role (Lapierre \& Allen, 2012). Work life conflict is used interchangeably with work family conflict as a form of inter-role conflict due to incompatibility in the performance of work and family roles. Chou \& Cheung state two forms of conflict, namely strain-based (when stress of one role is transferred to another) and time-based (when time demand for one role absorbs that for the other role) (Chou \& Cheung, 2013). Working mothers continue to hold a larger share of domestic and care work than their husbands and experience higher rates of tension between work and family obligations (Fahlén, 2016). Furthermore, it is widely recognized that work-life interactions are context-dependent and that the national context, including public policy, expectations and values, intersects with the organizational context (Stavrou, Casper, \& Lerodiakonou, 2015).

In 1977, Marks points out that the endless feeling of tension or conflict arises due to the view that work and family are distinct units that strive for devotion (time and energy) at the same time (Marks, 1977). Past researchers ignored WLC, but since the demarcation amongst job obligation and family commitment is unclear employees often come across heightened conflict. Scholars must develop a sound consideration of both pressures generated by competing priorities of work and family roles creating burden (Tims, Bakker, \& Derks, 2014). It increases in situations where the work extremely affects family commitment for example: Employees being a care-provider such as an employee becoming father to a new born child will need some time with his family but important deadlines are stressing him and the 


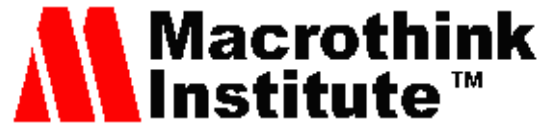

manager threatens him with termination if he fails at doing his work, which intensifies work-family conflict.

\subsection{Employee Engagement (EE)}

Work engagement is a productive job-related state of mind defined by vigor, concentration and dedication to work. (Schaufeli \& Bakker, 2004) and is defined as "emotional and intellectual commitment to the organization" (Shaw, 2005) (Richman, 2006) or "the amount of discretionary effort exhibited by employees in their jobs" (Frank, Finnegan, \& Taylor, 2004 ). Engagement refers to job and organization engagements i.e. one's contribution to work and organization that combines "intensive use of cognitive, emotional and behavioral resources" at work in accordance with the goals and objectives of the organization (Shuck \& Wollard, 2010). Kahn (1990 \& 1992) defines EE as psychological presence while carrying out work role whereas (Harter, Schmidt, \& Hayes, 2002) ascribe EE as, "An employee's involvement with, commitment to, and satisfaction with work". Numerous researchers have found that EE has a strong influence on employee commitment, sense of duty and retention (Saks, 2006). Researchers have a strong interest in EE, as it appears to produce positive outcomes and can serve as a driving force behind retention by reducing turnover intentions.

As Saks (2006) states that engagement defines the degree to which a person is concentrated as well as consumed by his/her position, it explains a range of ideas such as work achievement and corporate commitment and burnout (Babcock-Roberson \& Strickland, 2010). The difference between the expectations and the amount of support they receive from the organization with which they work is referred to as the gap in care or the gap in engagement, which is noted by many researchers. Such positive offers may include FWAs or training and development services that inspire workers to stay with the company (Truss, Shantz, Soane, Alfes, \& Delbridge, 2013).

\subsection{Work-life Enrichment (WLE)}

Work-life defined by researchers describes work as a paying job and everything beyond this fine line as life, while workers play different roles and their personalities enrich as they adapt to meet the conflicting demands of work-life domains (Greenhaus \& Powell, 2006). A significant body of empirical work has established its implications (Chen, Zhang, Sanders, \& $\mathrm{Xu}, 2016)$. WLE arises when skills, flexibility, social (supervisor support), psychological (self-confidence) and material resources (financial) formed during course of actions performed in one domain improve and influence psychological state of another domain. For example, conflict resolution skills gained in training at work will also allow workers to resolve disputes more effectively within their families (Beham, Drobnič, Präg, Baierl, \& Lewis, 2020). Thus, job supports family by enhancing personal goodness and family job may benefit by reducing stress or tiredness (Bhargava \& Baral, 2009).

Greenhaus and Powell (2006) defined WLE as, "The extent to which experience in one role improves the quality of-life namely, performance or affect, in the other role." WLE represents interdependent and complementary work and family practices (Werbel \& Walter, 2002). The presence in both positions does not always overlap, because they affect the other function 


\section{Macrothink}

domain positively. This fluidity between work and life can produce enriching effects that spill over workers into life (McMillan, Morris, \& Atchley, 2011).

\subsection{Time Planning Behavior (TPB)}

Planning is a behavior that aim at achieving an effective use of time while performing certain goal-directed activities (Claessens, van Eerde, Rutte, \& Roe, 2007). Planning activity is a central aspect of time management. Time management can be divided into organizing events, defining short and long-term priorities, and avoiding interruptions while working (Douglas, Bore, \& Munro, 2016). Time management in combination with organizational influences has gained little research attention.

In 1983, Feather and Bond found that people who structure their time are reported to positive tendencies like good mental and physical health, optimistic and more hopeful about future, more efficient with work and less anxious or depressed. Ineffective time management leads to stress and failing results, such as not being able to assign time or facing last-minute deadlines (Claessens, Van Eerde, Rutte, \& Roe, 2004).

\subsection{Theoretical Framework}

We welcomed Azar et. al (2018) call for research and modified their model by studying FWAs impact on work-life enrichment and engagement. We tested flexible working arrangements (FWA), affective organizational commitment (AOC), employee engagement (EE), work-life conflict (WLC), and work-life enrichment (WLE) collectively, as together no study has focused on these variables. We also studied the moderating effects of time planning behavior (TPB) on WLC as was done by Azar et. al. (2018), but we also studied the moderating effect of TPB on EE which has not been studied ever before. Planning is a strong predictor of time management skills enabling people to organize and schedule work related activities and providing them with more balance with work/life obligations. It is likely that by using effective planning skills employees can reap complete benefits of FWAs. Hence, this is a novel attempt as no such study is conducted in the world, which is exploring the effects of FWAs usage on work-life enrichment in a mediatory framework along with complementarity effect.

Figure 1 shows the model as described above with FWA as the independent variable and likewise AOC as the dependent variable, while the blue arrows are drawn to identify our testing hypotheses explained briefly in our next section. 


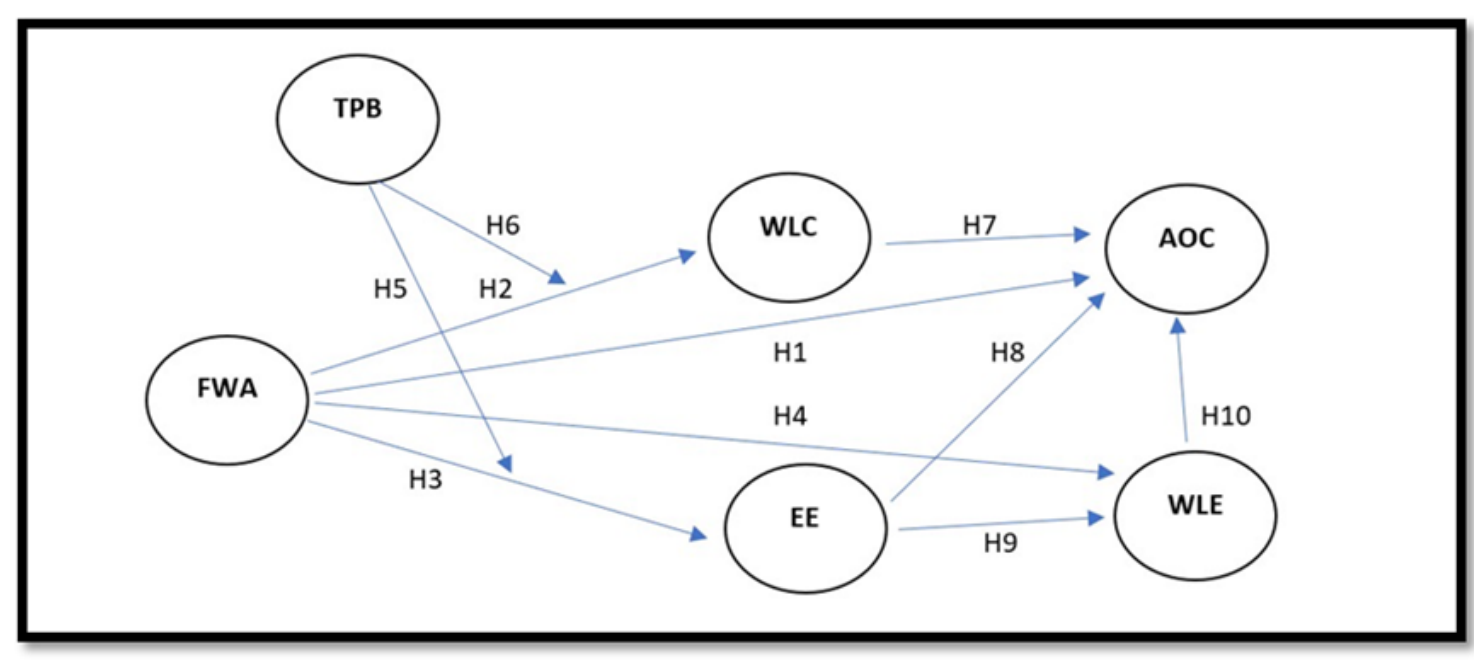

\subsection{Hypotheses Development}

2.8.1 Relationship between usage of flexible work arrangement and affective organizational commitment

Previous researches determined that flexible working arrangements influence organizational commitment (Maxwell, Rankine, Bell, \& MacVicar, 2007). Therefore, researchers continuously study flexible work arrangements as its advocated as means of growing commitment among employees (Cotti, Haley, \& Miller, 2014) (De Menezes \& Kelliher, 2017). Flexible working practices indicate better commitment with reduced intents of turnover (Burud \& Tumolo, 2004). FWAs becomes essential for all workers, although it was chiefly considered for middle-age workers (Allen, Johnson, Kiburz, \& Shockley, 2013) but the aforementioned is used mainly for attracting, engaging, developing and retaining talents (Burke \& Cooper, 2006). Organizations employing flexibility in workplace aim at maintaining employee enthusiasm and effective performance (Herrbach, Mignonac, Vandenberghe, \& Negrini, 2009) (Ramakrishnan \& Arokiasamy, 2019). FWAs effects constructively on organizational commitment, creating favorable impacts on reducing WLC (Glass \& Finley, 2002) (Choo, Desa, \& Asaari, 2016). Workers with FWAs are more loyal than those who do not use these flexible working options. Hence, flexibility will induce greater commitment. Thus, a noteworthy assumption is that flexible working arrangements positively influence affective commitment, portraying the expected social exchange (Blau, 1964) (Odle-Dusseau, Britt, \& Greene-Shortridge, 2012). We hypothesize that:

Hypothesis 1: There exists a significant relationship between usage of flexible working arrangement and affective organizational commitment.

2.8.2 Relationship between usage of flexible working arrangement and work-life conflict:

Organizations among various cultures have started to adopt family-friendly policies as 
they're identified as important means to sustain balance in work life with juggling priorities. Past research studies the relationship between flexible working conditions and work-life conflict, which clarified that flexible work entails less work-life conflict (Hill, Yang, Hawkins, \& Ferris, 2004) (Hammer, Neal, Newsom, Brockwood, \& Colton, 2005). Flexible workplace practices have helped with reducing WLC as studied recently (Erden Bayazit \& Bayazit, 2019) (Talukder, 2019). According to Byron, flextime maybe most effective with avoiding conflict (Byron, 2005). However, some studies reported that there was no relationship (Anderson, Coffey, \& Byerly, 2002). Most practitioners remain interested in finding a clear and thoughtful relation among them.

The indirect beneficial effect of flexible employment on employee attitudes towards improving mental and physical health is illustrated by a consequent decrease in conflict. Glass and Finley have concluded that FWAs have a positive effect on well-being and help mitigate work-family tensions (Glass \& Finley, 2002), allowing workers to balance their work and family commitments well. The literature has defined FWAs as tools for enhancing work-life integration and reducing WLC (Barnett \& Hall, 2001) (Lewis, Smithson, Cooper, \& Dyer, 2002). Briefly, flexible work policies are the efforts exerted by practitioners to allow human resources to handle conflict within work and family domains (Golden, 2001). We hypothesize that:

Hypothesis 2: There exists a significant relationship between usage of flexible working arrangement and work-life conflict.

2.8.3 Relationship between usage of flexible working arrangement and employee engagement:

Recent interest drawn on engagement and FWAs (Maden, 2015), shows how employees use FWAs to increase means to reach work-related goals and gain perceived control which also impact on psychological well-being (Halbesleben, Neveu, Paustian-Underdahl, \& Westman, 2014). Recent researches show how flexibility at work was negative because it reduced employee social interaction and input (Ter Hoeven \& Van Zoonen, 2020). Others found that, FWAs increase engagement at work which brings many positive outcomes (Gerards, de Grip, $\&$ Baudewijns, 2018) and reduces burn out stress syndrome (BOSS) by providing more work-life balance (Stairs, 2005). According to (Bakker \& Demerouti, 2007), resources in the work environment provide balance to the demands of work and maintain mental health of the employees. It is the option of how an employee operates (Behson, 2005) with other structures of control and freedom that connects FWAs and employee involvement therefore, providing more autonomy to workers is a very effective way to increase their engagement (De Spiegelaere, Van Gyes, \& Van Hootegem, 2016). In 2015, Bal and Lange found that the availability of FWAs would give workers more energy to invest in work to combat the possible pressures of disruption of work-life commitments (Bal \& De Lange, 2015). Higher employee commitment is therefore related to the use of flexibility. We hypothesize that:

Hypothesis 3: There exists a significant relationship between usage of flexible working arrangement and employee engagement. 
2.8.4 Relationship between usage of flexible working arrangement and work-life enrichment:

FWAs play a significant role in the process of resource generation by enhancing work-to-family enrichment (Greenhaus \& Powell, 2006). Based on the principle of exchange, adopting family-friendly policies means that the company has a favorable attitude towards workers. Previous findings show that flexibility improves the influence of workers over work and family issues (Allen, Johnson, Kiburz, \& Shockley, 2013), enhancing enrichment as a result (Wayne, Casper, Matthews, \& Allen, 2013) (Chan, et al., 2016) (Beham, Drobnič, Präg, Baierl, \& Lewis, 2020).

Hence, flexibility enables individuals to control time which provides them confidence to fulfill their family responsibilities and work obligations and even save time (Bond \& Wise, 2003). WLE targets the intensified benefits across work and life domains. Thus, being valuable to study enrichment to augment our consideration of the interaction within work and non-work roles. Besides, it may relax the barriers that separate work from life, allowing for a more widespread transfer of benefits to the family, as well as the acceptance of life outside work (Matthews, Barnes-Farrell, \& Bulger, 2010). Therefore, a positive correlation with work-to-family enrichment is predicted based on theory and past studies. We hypothesize that:

Hypothesis 4: There exists a significant relationship between usage of flexible working arrangement and work-life enrichment.

\subsubsection{Relationship between time planning behavior and engagement:}

Planning behaviors of goal-setting and prioritizing lead to proper management and control of time, creating engagement and well-being of employees by increasing employee satisfaction (Tims M. , Bakker, Derks, \& Van Rhenen, 2013). Planning helps people to organize their jobs in line with available resources and incentives to improve the probability of completing job/task and feel less overwhelmed by jobs (Claessens, Van Eerde, Rutte, \& Roe, 2004). In 1990, Macan suggested that a person who regularly engages in planning will not experience tasks/job pressure or stress at work and will improve performance (Macan, Shahani, Dipboye, \& Phillips, 1990). Time management skills are known as self-management (Claessens B. J., van Eerde, Rutte, \& Roe, 2007) and include setting goals using time management techniques to schedule and organize tasks. Therefore, those who are competent to use their time can develop plans to make the best of the time options offered by the FWA, whereas those less competent in time management will struggle to prioritize and schedule those options. As work-life priorities get more complex (Vuori, Toppinen-Tanner, \& Mutanen, 2011) with an increased emphasis on continuous learning workers will become more engaged by administering principles of self-management (Akkermans, Schaufeli, Brenninkmeijer, \& Blonk, 2013). Hence, contemporary researchers are starting to acknowledge that planning plays an important part in work engagement (Sonnentag, 2012). We hypothesize that:

Hypothesis 5: There exists a significant relationship between time planning behavior and engagement.

2.8.6 Relationship between time planning behavior and work-life conflict: 


\section{MInstitute ${ }_{\text {Mnin }}^{\text {Macrothin }}$}

Individuals have a limited time bound by various constraints/restrictions (Kooij \& Van de Voorde, 2011) therefore, its essential to develop time management skills in today's competitive and changing world. Past researches on time management have identified behaviors including setting goals/priorities and making lists/schedules therefore, we see that planning is a personal characteristic that particularly reduces conflict we note that, workers who manage their time effectively experience less WLC. In 1994, Macan suggested that planning behavior reduce strains (time-based conflicts) such as job dissatisfaction and health complaints through the control of time (Macan, 1994). WLC for workers is found to be especially dependent on how effectively employees manage time because few studies link FWA and time management and researched the potential benefits of time management actions concerning WLC (Lapierre \& Allen, 2012) (Gold \& Mustafa, 2013). Thus, solution proposed by Lapierre and Allen, for eradicating work life conflict is to execute planning behavior in their everyday lives (Lapierre \& Allen, 2012). The combination of planning with usage of FWAs will assist in enhancing the effect of FWAs. We hypothesize that:

Hypothesis 6: There exists a significant relationship between time planning behavior and work-life Conflict.

\subsubsection{Relationship between work-life conflict and affective organizational commitment:}

Researchers back the awareness of lower WLC associated with advanced commitment leading to higher loyalty to an organization (Eby, Casper, Lockwood, Bordeaux, \& Brinley, 2005) (Madsen, John, \& Miller, 2005) (Choo, Desa, \& Asaari, 2016) because they want to (affective commitment). A meta-analysis showed that work-family interference (WFC) and family-work interference (FWC) decreases AOC (Allen, Herst, Bruck, \& Sutton, 2000). Several researchers proved that WLC decreases AOC (Streich, Casper, \& Salvaggio, 2008) (Lambert, Liu, Jiang, Kelley, \& Zhang, 2020) whereas, some did not find the same (Zhang, Griffeth, \& Fried, 2012) proposing that these associations didn't appear reliable while others found no significant relationship (Casper, Martin, Buffardi, \& Erdwins, 2002) WLC arises probably due to demanding family roles. Practically WLC will generate a reduced amount of loyalty thus reducing affective commitment. Nevertheless, affective commitment is consistently robust predictor of consequences such as retention, satisfaction and engagement (Rhoades, Eisenberger, \& Armeli, 2001). We hypothesize that:

Hypothesis 7: There exists a significant relationship between work-life conflict and affective organizational commitment.

2.8.8 Relationship between employee engagement and affective organizational commitment:

Engagement is beneficial for Commitment. Past researchers found that organizational support is linked to motivational variables (Poon, 2013), which is a fulfilling work-related state characterized by vigor, dedication and absorption (Schaufeli, Salanova, González-Romá, \& Bakker, 2002). Job resources include, "psychological, social, or organizational aspects of the job that are functional in achieving work related goals and stimulate personal growth learning and development" (Bakker \& Demerouti, 2007), these directly motivate employees to feel valued and are likely to become loyal (Poon, 2013). Individuals who are really dedicated to 
their job have a greater engagement and are more involved than their less engaged peers (Weer \& Greenhaus, 2020). Research indicates that engagement evolves through the exchange principle that workers associate with organizations that tend to be committed to them and deliver the desired outcomes (Richman, Civian, Shannon, Jeffrey Hill, \& Brennan, 2008). Supportive work environment is positively related to employee engagement (Nahrgang, Morgeson, \& Hofmann, 2011). When employee believe that the organization supports them, their emotional attachment strengthens their organizational commitment levels. This belief boosts motivation and engagement levels. We hypothesize that:

Hypothesis 8: There exists a significant relationship between employee engagement and affective organizational commitment.

\subsubsection{Relationship between engagement and work-life enrichment:}

(Carlson D. , Kacmar, Wayne, \& Grzywacz, 2006) found mostly our purpose to work is to support our family/ourselves which is the motivation for improved work performance. Work that offers a sense of fulfillment bestows workers with a gratitude of achievement leading to success translating confidence into non-work lives of workers, allowing them to become better family members. In 2010, Siu studied that work engagement significantly mediates the linking of FWAs and WLE (Siu, et al., 2010). In 2012, (Chen \& Powell, 2012) also confirmed that engagement will create resource benefits and indicated that it was an antecedent of enrichment. It is also predictable how employers are likely to envisage means of enrichment in work life for their motive of achieving productivity gains for own sake or mainly for enriching work life. We stress the importance of work-family roles in keeping workers in a good mood and promoting a sustained degree of engagement that is supposed to confirm clear ties between engagement and enrichment. In line with (Ryan \& Deci, 2001) predictions, the occurrence of a robust link between a sense of meaningfulness and fulfillment, psychological well-being and personal happiness that transcends boundary demarcations in people's lives, we hypothesize that:

Hypothesis 9: There exists a significant relationship between engagement and work-life enrichment.

\subsubsection{Relationship between work-life enrichment and affective organizational commitment:}

Affective organizational commitment reflects emotional involvement of an employee. It is observed that the ability of an individual to integrate work/family roles should positively influence emotional response, irrespective of the directions of enrichment. Individuals experiencing work-life enrichment develop gratification, which can be originated from work leading to commitment (Wayne, Randel, \& Stevens, 2006). In meta-analysis of WLE (McNall, Nicklin, \& Masuda, 2010), McNall distinguished associations among enrichment and affective commitment. Researchers found positive relationship between WLE and AOC (Balmforth \& Gardner, 2006) (Wayne, Casper, Matthews, \& Allen, 2013) whereas, others did not find the same (Hill E. J., 2005). We hypothesize that:

Hypothesis 10: There exists a significant relationship between work-life enrichment and affective organizational commitment. 


\section{Research Method}

\subsection{Sampling and Procedure}

Purposive sampling can be defined as a subtype of "Non-probability sampling". It is defined as a sampling which allows researcher to select the participants using their own judgment and decisions (Mackey \& Gass, 2015). Similarly, purposive sampling also deemed as selective and judgmental sampling technique. It can be simply defined as a non-random sampling in which the scholar chooses what information is required and decide the relevant individuals that could provide the specific data based on the virtue of knowledge (Tongco, 2007). Therefore, the current study has aimed to use purposive sampling for data collection. The reasons for using purposive sampling were that it allowed the researcher to gather knowledge via certain experts from the specific targeted population or domain. It also helped in directly communicating to the participants and generates required knowledge and results regarding research objective. Initially, emails were sent to employees of various multinational companies operating in Karachi city, requesting them for a voluntary participation with survey link attached, along with that most of the primary data was collected online and some of it was manually collected by distributing the questionnaire among employees.

\subsection{Questionnaire Designing}

Questionnaire contains two portions: first data of demographics is collected then there are questions regarding each variable on which this research is being conducted. Questionnaire comprises of sections, as follows:

Section-I covered the demographics as shown in Table A.

Section-II covers the AOC adopted from “Allen and Meyer's (1990) scale for measurement of organizational commitment" (Allen \& Meyer, 1990), using 5 items and were rated on a 5-point Likert Scale labeled 1 to 5 (strongly disagree to strongly agree).

Section-III consist of 7 questions of FWA to measure using a 7-point scale from 7 to 1 (Full control to no control) established by (Crowley \& Kolenikov, 2014).

Section-IV consists of 5 items from WLE established by (Carlson D., Kacmar, Wayne, \& Grzywacz, 2006) used to measure work-life enrichment on a 5-point Likert scale from 1 to 5 (strongly disagree to strongly agree).

Section-V consists of 5 items of EE by using "Utrecht Work Engagement Scale (UWES)" developed in 2003 (Schaufeli \& Bakker, 2003) to assess engagement on a 7-point scale, ranging from "never" to "always, every day."

Section-VI consists of 5 items from WLC developed by (Carlson, Kacmar, \& Williams, 2000), the items were to be rated on a 5-point Likert scale from 1 to 5 (strongly disagree to strongly agree).

Section-VI consists of 5 items from TPB by (Macan, Shahani, Dipboye, \& Phillips, 1990) on a 5 -point Likert scale from 1 to 5 (strongly disagree to strongly agree). 


\subsection{Demographics Analysis}

Table 1. Demographics

\begin{tabular}{|c|c|c|c|}
\hline & CATEGORY & FREQUENCY & PERCENTAGE \\
\hline \multirow{2}{*}{ GENDER } & Male & 150 & $50 \%$ \\
\hline & Female & 150 & $50 \%$ \\
\hline \multirow[t]{2}{*}{ SERVICE SECTOR } & Public & 118 & $39.3 \%$ \\
\hline & Private & 182 & $60.6 \%$ \\
\hline \multirow[t]{3}{*}{ EDUCATION } & Non-graduate & 06 & $0.02 \%$ \\
\hline & Graduate & 178 & $59.3 \%$ \\
\hline & Post-graduate & 116 & $38.7 \%$ \\
\hline \multirow{4}{*}{$\begin{array}{ll}\text { NUMBER } & \text { OF } \\
\text { DEPENDENTS } & \end{array}$} & Elderly & 133 & $44.3 \%$ \\
\hline & Children & 62 & $20.7 \%$ \\
\hline & Both & 63 & $21 \%$ \\
\hline & None & 42 & $14 \%$ \\
\hline \multirow[t]{3}{*}{ EXPERIENCE (YEARS) } & $1-5$ years & 147 & $49 \%$ \\
\hline & $6-10$ years & 119 & $39.7 \%$ \\
\hline & Above 10 years & 34 & $11.3 \%$ \\
\hline \multirow{2}{*}{$\begin{array}{l}\text { TIME TRAVELED } \\
\text { (IN MINUTES) }\end{array}$} & Less than 60 minutes & 111 & $37 \%$ \\
\hline & $\begin{array}{l}\text { More than } 60 \\
\text { minutes }\end{array}$ & 189 & $63 \%$ \\
\hline
\end{tabular}

A sample of 300 respondents was used comprising of 150 males (50\%) and 150 females (50\%), out of which 118 were public/government employees and 182 had private sector jobs. Age of respondents is measured in terms of age distribution of less than 35 years old to equal/greater than 35 years old among which $88.3 \%$ (265 out of 300) of respondents were aged less than 35 and $11.7 \%$ (35 out of 300 ) were equal or greater than 35 years of age. Educational level was also assessed it showed that $178(59.3 \%)$ respondents were graduates, $116(38.7 \%)$ were post-graduates and $6(0.02 \%)$ among them were non-graduates. The number of dependents they had was categorized into elders, children, both and none out of which $133(44.3 \%)$ said they had elders ( like parents) to take care of, $62(20.7 \%)$ respondents had children dependent on them for their time and other resources, 63 (21\%) had to take care of both elders and children in their family while $42(14 \%)$ respondents believe they do not have any one depending on them. Years of working experience was also required for understanding their commitment to work and out of 300, 147(49\%) had experience between 1 to 5 years, $119(39.7 \%)$ had between 6 to 10 years' experience and $34(11.3 \%)$ had experience $>10$ years. Time they travel to work (door to door) in both directions from work to home and vice-versa was assessed in minutes less than 60 and more than 60 minutes, 


\section{Macrothink}

$111(37 \%)$ responded that it takes less than 60 minutes for them to travel while $189(63 \%)$ responses recorded show that it took more than 60 minutes for them to travel.

\section{Results}

\subsection{Common Method Bias (CMB)}

The main reason researchers are worried about common method bias is due to Path coefficient inflation effect as it may cause type I (false positive) errors or the effect of path coefficient deflation, leading to type II errors (false negatives). According to Kock (Kock, 2015), the variance inflation factors (VIF) for reflective and formative constructs may be used to determine the common method bias resulting from the full collinearity test using PLS-SEM. A higher tolerance level of 5.0 is recommended, but a threshold of 3.3 is used more frequently. As all the inner VIF values in table 2 are below 3.3, we conclude that our model is free from CMB.

Table 2.

\begin{tabular}{|l|l|l|l|l|}
\hline $\begin{array}{l}\text { Table 2: } \\
\text { Inner VIF Values }\end{array}$ & $\begin{array}{l}\text { Affective } \\
\text { Organizational } \\
\text { Commitment }\end{array}$ & $\begin{array}{l}\text { Employee } \\
\text { Engagement }\end{array}$ & $\begin{array}{l}\text { Work } \\
\text { Life } \\
\text { Conflict }\end{array}$ & $\begin{array}{l}\text { Work Life } \\
\text { Enrichment }\end{array}$ \\
\hline $\begin{array}{l}\text { 1. Affective Organizational } \\
\text { Commitment }\end{array}$ & & & & 1.644 \\
\hline 2. Employee Engagement & 2.055 & 1.511 & 1.511 & 1.888 \\
\hline 3. FWAs use & 2.056 & & 1.038 & \\
\hline Moderating Effect 1 & & 1.038 & 1.551 & \\
\hline Moderating Effect 2 & & 1.551 & & 1.338 \\
\hline 4. Time Planning Behaviour & & & & \\
\hline 5. Work Life Conflict & 1.423 & 1.734 & & \\
\hline 6. Work Life Enrichment & & & & \\
\hline
\end{tabular}

\subsection{Descriptive Statistics}

Descriptive analysis is completed to grasp comprehensive gain from statistics. To identify the strength of relationships between all variable, correlations are calculated (Zou, Tuncali, \& Silverman, 2003).

Figures from descriptive statistics table 3 in appendix, show that all the items have outer loading values greater than 0.70 indicating stronger loading values except for item number 5 from time planning behavior (TPB). The values of T-statistics are supported and are more than 1.96 for all items (with $p$ value of 0.000 ) indicating their significance. 


\subsection{Structural Equation Modeling (SEM):}

SEM is a useful statistical tool for multivariate data analysis, popular with social and behavioral studies therefore, we used this technique to test hypotheses using Smart PLS software. Testing of all constructs was done to assess the direct links along with indirect links through PLS-SEM (variance-based SEM). SEM is found as the key technique used in models for regression, as it tests the association amongst exogenous and endogenous variables, including factor and multivariate analysis (Baron \& Kenny, 1986). Regression equation describes each construct when evaluating the causal relationship at the same time. For testing both direct and indirect effects, the method implemented is known as bootstrapping (Shrout $\&$ Bolger, 2002). The model was used to implement the bootstrapping technique because it is appropriate for any number of sample size (Hayes, 2013).

\subsubsection{Model Fit Measures:}

In PLS-SEM, the fitness of the model is measured by metrics such as the uniform root mean-square residual (SRMR) and the exact model fits such as d ULS, d G, the Normed Fit Index (NFI) and $\chi^{2}$ (Chi-square). Both measurements indicate the importance of both the saturated model and the predicted model as seen below. The Saturated model measures the association of all structures, while the estimate model considers the meta-structure and draws on the overall results.

According to the standards, SRMR must be less than 0.08 for good fit of the model and NFI must be closer to 1 for a better fit, results can be seen below. NFI does not penalize for model complexity, the more the parameters the greater the NFI that's why this measure is not recommended. A better alternative measure is Non-normed fit index (NNFI) but it's not implemented yet in the software used i.e. SmartPLS.

Table 4. Fit Summary

\begin{tabular}{|l|l|l|}
\hline Table 4: & Saturated Model & Estimated Model \\
\hline SRMR & 0.055 & 0.060 \\
\hline d_ULS & 1.487 & 1.801 \\
\hline d_G & 0.649 & 0.673 \\
\hline Chi-Square & 1137.053 & 1172.033 \\
\hline NFI & 0.843 & 0.839 \\
\hline
\end{tabular}

R-square measures goodness-of-fit for linear regression models showing the proportion of variation in the dependent variable that is jointly described by the independent variable (Frost, 2017). R-square values ranges between 0 to 1 , higher values indicate greater predictive accuracy of the model, Table 5 shows $58.3 \%, 45.3 \%, 29.2 \%$ and $42.3 \%$ of variance in the variables respectively. 


\begin{tabular}{|l|l|l|}
\hline Table 5: & R Square & R Square Adjusted \\
\hline 1. Affective Organizational Commitment & 0.583 & 0.577 \\
\hline 2. Employee Engagement & 0.453 & 0.447 \\
\hline 3. Work Life Conflict & 0.292 & 0.285 \\
\hline 4. Work Life Enrichment & 0.423 & 0.417 \\
\hline
\end{tabular}

\subsection{Measurement of Outer Model}

In order to find out that the measurements of the outer model are correct, we check the reliability and validity by performing a Convergence Validity and Discrimination Test using Smart PLS software.

\subsubsection{Composite Reliability}

Reliability means the accuracy of the questionnaire findings as with the same target audience if the researcher re-uses a questionnaire that would yield comparable outcomes. It shows that the consistency and repeatability of the survey are high to maintain a deliberate distance from the injustice of research at this point and is improved by testing the investigation procedure using research analysis techniques by different researchers. This also incorporates the precision and acceptability of the analysis. It is evaluated using composite reliability for the measured instruments (Shook, Ketchen, Hult, \& Kacmar, 2004) using standard of 0.7. Table 6 shows that all values confirm reliability. The estimate of reliability can be rendered by the degree of constancy between the variables (Hair J. F., 2010).

\subsubsection{Convergent Validity:}

To test the convergent validity, the Average Variance Extracted (AVE) of each latent variable is evaluated (Wong, 2013), as it shows the agreement level of constructs (Carmines \& Zeller, 1979). It is judged by reviewing the variances extracted for every factor, if this value is greater than acceptable threshold 0.5. The convergent validity is then calculated, and the loadings are fine, those less than 0.5 are found to be less successful for the analysis (Fornell \& Larcker, 1981). Here, AVE values are greater than 0.5 (as shown in table 6).

\begin{tabular}{|l|l|l|l|}
\hline Table 6: & $\begin{array}{l}\text { Cronbach's } \\
\text { Alpha }\end{array}$ & $\begin{array}{l}\text { Composite } \\
\text { Reliability }\end{array}$ & $\begin{array}{l}\text { Average Variance } \\
\text { Extracted (AVE) }\end{array}$ \\
\hline 1. Affective Organizational Commitment & 0.917 & 0.938 & 0.751 \\
\hline 2. Employee Engagement & 0.872 & 0.907 & 0.662 \\
\hline 3. FWAs use & 0.925 & 0.941 & 0.727 \\
\hline 4. Time Planning Behaviour & 0.755 & 0.837 & 0.521 \\
\hline 5. Work Life Conflict & 0.948 & 0.960 & 0.829 \\
\hline 6. Work Life Enrichment & 0.882 & 0.914 & 0.680 \\
\hline
\end{tabular}




\subsubsection{Discriminant Validity:}

Fornell-Larcker Criterion suggest that, "the square root of AVE of each latent variable is used to establish discriminant validity, if this value is larger than other correlation values among the latent variables" (Fornell \& Larcker, 1981). Discriminate validity can be defined as, "any single construct in model that differs from other constructs" (Carmines \& Zeller, 1979). When constructs have an AVE loading more than 0.5 it is acceptable (Chin, 1998). Discriminate validity is established if values in diagonal are expressively higher than those parallel in rows and columns off-diagonally. This test shows whether unrelated theories or tests are correlated. Off-diagonal we have the correlations and on diagonal is the square roots of the AVE which is good as all values are above 0.7 .

For example, EE's AVE value is 0.662 (from Table 6) henceforth, its square root becomes 0.813 (shown in table 7). This number is greater than the correlation values in EE column (starting from 0.622 to 0.599 ) and larger than those in the row (0.620). The rest of the latent variables have been similarly observed, indicates that discrimination is well established (Wong, 2013).

\begin{tabular}{|l|l|l|l|l|l|l|}
\hline Table 7: & 1 & 2 & 3 & 4 & 5 & 6 \\
\hline $\begin{array}{l}\text { 1. Affective Organizational } \\
\text { Commitment }\end{array}$ & 0.866 & & & & & \\
\hline 2. Employee Engagement & 0.620 & 0.813 & & & & \\
\hline 3. FWAs use & 0.727 & 0.622 & 0.853 & & & \\
\hline 4. Time Planning Behaviour & 0.539 & 0.568 & 0.582 & 0.722 & & \\
\hline 5. Work Life Conflict & -0.410 & -0.367 & -0.497 & -0.316 & 0.910 & \\
\hline 6. Work Life Enrichment & 0.498 & 0.599 & 0.504 & 0.554 & -0.112 & 0.825 \\
\hline
\end{tabular}

\subsection{Hypothesis Testing}

In PLS-SEM, bootstrapping is one of the key steps to ensure the reliability of the data for factor estimation. Sub-tests shall be taken from the primary example, including substitution, in this course of action (Hair, Matthews, Matthews, \& Sarstedt, 2017) bootstrapping provides information for stability of coefficient estimate. Many sub-samples are drawn from the original sample with the replacement technique (Streukens \& Werelds, 2016). After running the bootstrapping test, PLS-SEM displays the t-values for the structural model estimations resulting from the process. The results of the hypotheses path coefficients are shown in the table below. T-statistics indicates significance for t-values greater than $1.96(\mathrm{p}<.005)$ the relationship is important at 95 percent confidence level $(\alpha=0.05)$.

Most of these relationships are statistically significant and it shows that FWAs use has more 


\section{Macrothink Institute ${ }^{\mathrm{TM}}$}

significant impact on Affective Organizational Commitment (7.918), Work Life Conflict (8.119), Employee Engagement (7.907) and Work Life Enrichment (4.303). Time Planning Behavior has more significant impact on Employee Engagement (5.068) than on Work Life Conflict (1.283).

Moreover (From table 8), the P value of $0.000<0.05$ increases our likelihood to accept the following hypothesis. For example: H1, H2, H3 and $\mathrm{H} 4$ are supported as there is a significant (P-Value: 0.000) relationship between usage of FWA with AOC, WLC, EE and WLE respectively.

Similarly, H5, H8, H9 are supported but H6, H7 and H10 are not supported due to P value > 0.05 .

\begin{tabular}{|l|l|l|l|l|}
\hline Table 8: Path coefficient & $\begin{array}{l}\text { Original } \\
\text { Sample } \\
(\mathbf{O})\end{array}$ & $\begin{array}{l}\mathbf{T} \text { Statistics } \\
(|\mathbf{O} / \mathbf{S T D E V}|)\end{array}$ & $\begin{array}{l}\mathbf{P} \\
\text { Values }\end{array}$ & Results \\
\hline $\begin{array}{l}\text { H1. FWAs use -> Affective Organizational } \\
\text { Commitment }\end{array}$ & 0.505 & 7.918 & 0.000 & Supported \\
\hline H2. FWAs use -> Work Life Conflict & -0.471 & 8.119 & 0.000 & Supported \\
\hline H3. FWAs use -> Employee Engagement & 0.441 & 7.907 & 0.000 & Supported \\
\hline H4. FWAs use -> Work Life Enrichment & 0.311 & 4.303 & 0.000 & Supported \\
\hline $\begin{array}{l}\text { H5. Time Planning Behaviour -> Employee } \\
\text { Engagement }\end{array}$ & 0.319 & 5.068 & 0.000 & Supported \\
\hline $\begin{array}{l}\text { H6. Time Planning Behaviour -> Work Life } \\
\text { Conflict }\end{array}$ & -0.082 & 1.283 & 0.200 & $\begin{array}{l}\text { Not } \\
\text { Supported }\end{array}$ \\
\hline $\begin{array}{l}\text { H7. Work Life Conflict -> Affective } \\
\text { Organizational Commitment }\end{array}$ & -0.067 & 1.407 & 0.160 & $\begin{array}{l}\text { Not } \\
\text { Supported }\end{array}$ \\
\hline $\begin{array}{l}\text { H8. Employee Engagement -> Affective } \\
\text { Organizational Commitment }\end{array}$ & 0.217 & 2.793 & 0.005 & Supported \\
\hline $\begin{array}{l}\text { H9. Employee Engagement -> Work Life } \\
\text { Enrichment }\end{array}$ & 0.487 & 8.426 & 0.000 & Supported \\
\hline $\begin{array}{l}\text { H10. Work Life Enrichment -> Affective } \\
\text { Organizational Commitment }\end{array}$ & 0.106 & 1.622 & 0.105 & $\begin{array}{l}\text { Not } \\
\text { Supported }\end{array}$ \\
\hline
\end{tabular}

4.5.1. Moderation Analysis:

\begin{tabular}{|l|l|l|l|l|}
\hline Table 9: & $\begin{array}{l}\text { Original } \\
\text { Sample (O) }\end{array}$ & $\begin{array}{l}\text { T Statistics } \\
(|\mathbf{O} / \mathbf{S T D E V}|)\end{array}$ & $\begin{array}{l}\mathbf{P} \\
\text { Values }\end{array}$ & Results \\
\hline $\begin{array}{l}\text { 1. Moderating Effect 1 -> Work Life } \\
\text { Conflict }\end{array}$ & -0.229 & 4.474 & 0.000 & Supported \\
\hline
\end{tabular}




\section{Macrothink}

Human Resource Research

ISSN 1948-5441

2020, Vol. 4, No. 1

\begin{tabular}{|l|l|l|l|l|l|}
\hline $\begin{array}{l}\text { 2. Moderating Effect 2 } \\
\text { Engagement }\end{array}$ & 0.044 & 0.753 & 0.452 & $\begin{array}{l}\text { Not } \\
\text { Supported }\end{array}$ \\
\hline
\end{tabular}

From table 9, we note Moderating Effect (1) with WLC is statistically complimented, whereas Moderating Effect (2) with EE is not significant as its P-Value is 0.452.

Graph in figure 3 illustrates the interaction of usage of FWAs and time scheduling activity on work life interference. The values of standard deviation and mean of planning behaviour is analyzed and it intersects at a point of coordinates with values $(X, Y):(-0.44,0.18)$. We see that our result is consistent with Azar et al. (Azar, Khan, \& Eerde, 2018) research findings, showing how planning strengthens the negative relationship between the usage of FWAs and the Work-Life Conflict (WLC).

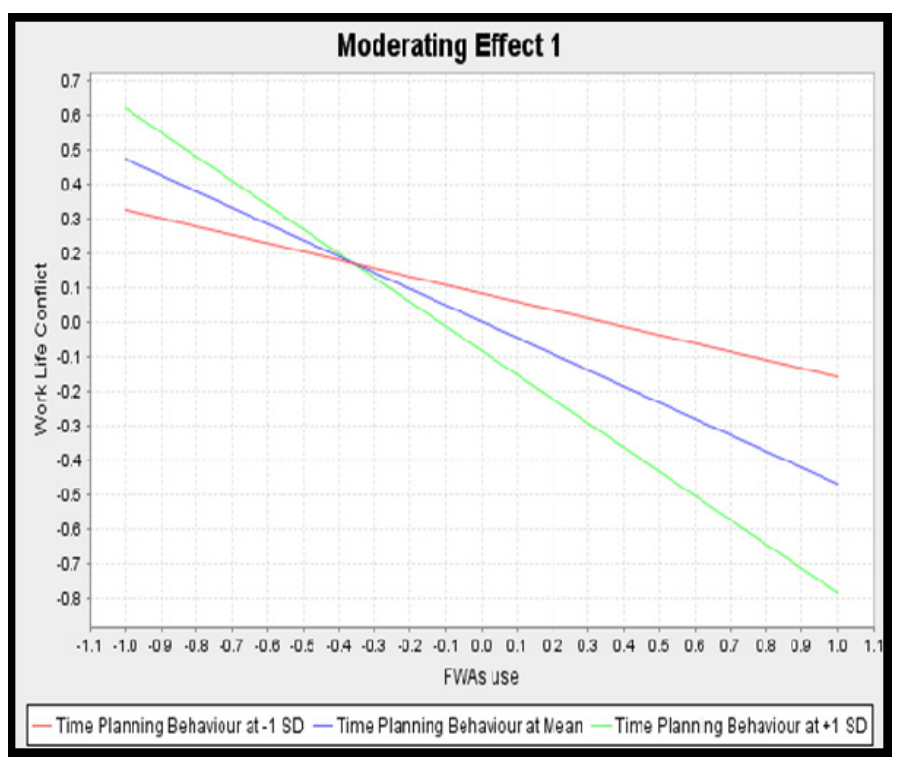

Figure 3. Moderation analysis graph

\subsubsection{Mediation Analysis:}

The first two reading from table 10, tells us that the mediation between FWAs use and Affective Organizational Commitment is occurring only through Employee Engagement. Similarly, readings number 3 and 4 show that both engagement and work-life conflict show meaningful meditation effects between FWAs use and work-life Enrichment.

The supported results from table 10: Specific indirect effects, shows the meaningful mediation effects.

\begin{tabular}{|l|l|l|l|l|}
\hline Table 10: Specific indirect effects & $\begin{array}{l}\text { Original } \\
\text { Sample } \\
(\mathbf{O})\end{array}$ & $\begin{array}{l}\text { T Statistics } \\
(|\mathbf{O} / \mathbf{S T D E V}|)\end{array}$ & $\begin{array}{l}\mathbf{P} \\
\text { Values }\end{array}$ & Results \\
\hline $\begin{array}{l}\text { 1. FWAs use -> Employee Engagement -> } \\
\text { Affective Organizational Commitment }\end{array}$ & 0.096 & 2.631 & 0.009 & Supported \\
\hline
\end{tabular}




\section{Ml Macrothink}

Human Resource Research

ISSN 1948-5441

2020, Vol. 4, No. 1

\begin{tabular}{|c|c|c|c|c|}
\hline $\begin{array}{l}\text { 2. FWAs use }->\text { Work Life Conflict }-> \\
\text { Affective Organizational Commitment }\end{array}$ & 0.031 & 1.376 & 0.169 & $\begin{array}{l}\text { Not } \\
\text { Supported }\end{array}$ \\
\hline $\begin{array}{l}\text { 3. FWAs use -> Employee Engagement -> } \\
\text { Work Life Enrichment }\end{array}$ & 0.215 & 6.263 & 0.000 & Supported \\
\hline $\begin{array}{l}\text { 4. FWAs use -> Work Life Conflict }->\text { Work } \\
\text { Life Enrichment }\end{array}$ & -0.104 & 3.468 & 0.001 & Supported \\
\hline $\begin{array}{l}\text { 5. FWAs use }->\text { Employee Engagement }-> \\
\text { Work Life Enrichment }->\text { Affective } \\
\text { Organizational Commitment }\end{array}$ & 0.023 & 1.572 & 0.116 & $\begin{array}{l}\text { Not } \\
\text { Supported }\end{array}$ \\
\hline $\begin{array}{l}\text { 6. FWAs use }->\text { Work Life Conflict }->\text { Work } \\
\text { Life Enrichment }->\text { Affective Organizational } \\
\text { Commitment }\end{array}$ & -0.011 & 1.466 & 0.143 & $\begin{array}{l}\text { Not } \\
\text { Supported }\end{array}$ \\
\hline $\begin{array}{l}\text { 7. FWAs use -> Work Life Enrichment -> } \\
\text { Affective Organizational Commitment }\end{array}$ & 0.033 & 1.530 & 0.126 & $\begin{array}{l}\text { Not } \\
\text { Supported }\end{array}$ \\
\hline $\begin{array}{l}\text { 8. Employee Engagement }->\text { Work Life } \\
\text { Enrichment }->\text { Affective Organizational } \\
\text { Commitment }\end{array}$ & 0.052 & 1.627 & 0.104 & $\begin{array}{l}\text { Not } \\
\text { Supported }\end{array}$ \\
\hline $\begin{array}{l}\text { 9. Work Life Conflict }->\text { Work Life } \\
\text { Enrichment -> Affective Organizational } \\
\text { Commitment }\end{array}$ & 0.024 & 1.527 & 0.127 & $\begin{array}{l}\text { Not } \\
\text { Supported }\end{array}$ \\
\hline $\begin{array}{l}\text { 10. Time Planning Behaviour }->\text { Work Life } \\
\text { Conflict }->\text { Work Life Enrichment -> } \\
\text { Affective Organizational Commitment }\end{array}$ & -0.002 & 0.961 & 0.337 & $\begin{array}{l}\text { Not } \\
\text { Supported }\end{array}$ \\
\hline $\begin{array}{l}\text { 11. Time Planning Behaviour }->\text { Work Life } \\
\text { Conflict } \rightarrow \text { Affective Organizational } \\
\text { Commitment }\end{array}$ & 0.005 & 0.831 & 0.406 & $\begin{array}{l}\text { Not } \\
\text { Supported }\end{array}$ \\
\hline $\begin{array}{l}\text { 12. Time Planning Behaviour }->\text { Work Life } \\
\text { Conflict }->\text { Work Life Enrichment }\end{array}$ & -0.018 & 1.320 & 0.187 & $\begin{array}{l}\text { Not } \\
\text { Supported }\end{array}$ \\
\hline $\begin{array}{l}\text { 13. Time Planning Behaviour }->\text { Employee } \\
\text { Engagement }->\text { Work Life Enrichment }\end{array}$ & 0.155 & 3.763 & 0.000 & Supported \\
\hline
\end{tabular}

\section{Discussion with limitations and future research recommendations}

Our research originated from observing the changes associated with work which is leading to a wider demand exhibited to FWAs (Burke \& Ng, 2006). We investigative the model of flexible work usage and with consistent mediators/moderator backed by evidence from the past. Our model as shown in figure 1 is satisfactory as the results show strong indication of discriminatory as well as convergent validity of the constructs used to record responses. The linkage between FWAs' use and affective commitment is strongest with presence of EE, WLE 
and lower WLC, which enhances well-being and creates balance in work and life domains of employee, which is a crucial insight of this linking and maximizes positive consequences by availing FWAs which benefit both the employee and the employer in terms of increased and effective performance. This assumption is worth exploring as there have been many key findings which are significant for study, theory and practice. (Chen, Zhang, Sanders, \& Xu, 2016) explored the relationship between flexible work arrangements and turnover intentions in terms of work to family enrichment, we studied affective commitment instead of turnover intentions to fulfil the gap in the literature in Pakistani context. Furthermore, this study did not address the likelihood of workers being dissatisfied with FWAs due to extra working hours as many workers spend tremendous energy to compensate for their lack of physical presence (Kelliher, Richardson, \& Boiarintseva, 2019), this aspect calls for further research especially in Pakistani context where people are made to work more than the remuneration they're paid.

Since the study has many practical and theoretical implications, the limitations of the present work need to be noted. Time to lead this examination was exceptionally restricted because of which longitudinal investigation could not be performed but our model can be tested using data from different cultures and countries. In future study, however, it would be better if multiple sources, including performance data, were used rather than attitudes. Finally, the utilization of cross-sectional self-reports poses questions about common method bias (CMB) and it is advised to be vigilant when conducting causal relationships. This study tested CMB and found no evidence that the data were affected. Our respondents were distributed around service sector industries and it is unclear whether this may have influenced the findings. It will be important to investigate how the effect of FWAs is influenced by industry-wide variations.

Our research revolves around the idea that after employees believe they're valued as proven by various organizational actions they're inclined to feel obliged to "pay back" by offering added commitment. We are pleased to continue to elaborate SET on the use of FWA, as it has been used for decades to understand the connection amongst workers and employers which has transformed from an economic exchange relationship into a high-quality social exchange relationship by the means of reciprocating responses (Cropanzano, Anthony, Daniels, \& Hall, 2017). We focused on distinction between conceptual and operational demarcation of the availability of FWAs and their usage (Allen, Johnson, Kiburz, \& Shockley, 2013). There exists a consistent support for FWA and AOC, stating that usage of FWA is significantly associated to AOC as supportive work-life policies predict an employee's affective organizational commitment consistent with recent findings of (Cotti, Haley, \& Miller, 2014) (De Menezes \& Kelliher, 2017). FWAs act as motivators that management implement to raise level of commitment, widely observed in case of female employees possessing work and family roles. We verify a significant relationship between FWA and EE, our study specifies that employees who use flexibility become more engaged than those who do not have the flexibility working options (Rupp \& Cropanzano, 2002) (Gerards, de Grip, \& Baudewijns, 2018). Our research also adds to the existing literature on FWAs and employee engagement which is very scant, recent researches (De Leede \& Heuver, 2017) (Peters, Poutsma, Vander 


\section{Macrothink}

Heijden, Bakker, \& Bruijn, 2014) support our findings showing that FWAs have positive effects on the performance of workers and both efficiency and organizational engagement. While this research primarily addressed younger generation workers and reflected their views, FWA is not only required for parents of young or special children, but workers who are senior make use of FWAs for leisure and rest (Bal \& De Lange, 2015). Flexible working arrangement is significant associated with WLC as caring environment with supportive policies removes the bottleneck in managing work life responsibilities which is consistent with recent findings (Erden Bayazit \& Bayazit, 2019) (Talukder, 2019). Employees become satisfied and experience work-life balance when perceive they can control their working schedule/work remotely. An individual with a strong preference for combining work and family roles or outstanding time management skills can be more likely to use FWA to prevent work from overtaking family roles. Thus, flexible working arrangements influence work-related attitudes/behaviors. Based on evidence that work to family enrichment mediates the relationship between FWAs and employee attitudes (Odle-Dusseau, Britt, \& Greene-Shortridge, 2012). Yet managers communicating and managing the flexibility options play significant role in employee usage of FWAs. Many conflicting reviews on flexible work arrangements exist whether they're good or bad for the well-being of workers are unique to the type of arrangement. Concerns regarding blurred lines between work and home roles emerge primarily from flexible arrangements. Negative job implications are related to part-time and other shortened working hours plans. Flextime practices, such as non-standard working hours, may be harmful to mental and physical health. It is therefore important to differentiate between the forms of flexible work arrangements (Chandola, Booker, Kumari, \& Benzeval, 2019). Across collectivistic societies families tend to be larger, it's common to host and accept unannounced visits from extended family members and friends compared to individualistic cultures (Le, Newman, Menzies, Zheng, \& Fermelis, 2020). As children and grandparents share the same household it becomes a busy place and may not be the best physical environment for working (Golden, Sweet, \& Chung, 2018). We further, find a significant and positive relationship between FWA and WLE which is consistent with McNall's research (McNall, Masuda, \& Nicklin, 2010; Wayne, Casper, Matthews, \& Allen, 2013), showing that the beneficial results of enrichment would benefit workers from flexible working conditions.

The association among WLC and AOC isn't supported, as WLC decreases AOC (Lambert, Liu, Jiang, Kelley, \& Zhang, 2020). In fact, previous studies find that the commitment to the employer is improved when workers believe that the boss is responsive to their work-life problems (Agarwala, Arizkuren-Eleta, Castillo, Muñiz-Ferrer, \& Gartzia, 2014). Employees with eldercare responsibilities experience high WLC, since work will interfere with their responsibilities as substantial resources of time and effort are limited (Duxbury, Higgins, \& Schroeder, 2009). Our research also suggests that, engagement influences enrichment. The knowledge and skills acquired along with emotions of personal fulfillment and accomplishment at work positively facilitates employee's personal life (Haar J. M., 2013). When work activities benefit personal life, it positively influences from work to home with active involvement in organizational activities (Menguc, Auh, Fisher, \& Haddad, 2013). Researchers called for research that further incorporates engagement and commitment as 


\section{$\Lambda$ Macrothink}

essential indicators of workers psychological linkages to their jobs (Albrecht, 2015) thus, our findings suggest that EE increases employee affective commitment consistent with previous researches (Weer \& Greenhaus, 2020)(Albrecht \& Marty, 2020). Manager's perceptions seem to be based on observational behavior and visible clues of their employees' commitment towards the organization. The connection of WLE and AOC was not supported therefore, organizations in Pakistan must try to stimulate experiences of enrichment by designing jobs. Workplace practices that foster employee empowerment (Kingma, 2019) can also promote a sense of commitment and satisfaction among employees at work that can contribute to WLE (Wayne, Casper, Matthews, \& Allen, 2013). Thus, when an employee notices the organization as family-supportive, positive feelings generate at work, employee becomes engaged and work hard to improve performance in order to reciprocate, which provides a sense of accomplishment which increases enrichment and commitment.

We observe from results that planning behavior significantly and positively affect employee engagement. When an employee is associated with higher planning behaviors, they keep setting goals and assigning priorities which help them maintain a balance. We see that in the presence of TPB (moderator), the influence of FWA usage on engagement did not find a meaningful effect. Individuals who have several opportunities to use their time may or may not make good use of it, which influences how they interpret WFC (Beigi, Shirmohammadi, $\&$ Stewart, 2018). The successful management of WFC is gradually becoming a self-management skill (Kossek \& Lautsch, 2012). We also observed that planning behavior negatively affects WLC, but the relation is insignificant whereas, the effect of FWAs' use on WLC is significant when effect of time planning is considered which is consistent to the findings of Azar et. al. 2018 (Azar, Khan, \& Eerde, 2018). We found a highly significant relationship between TPB and EE but not between TPB and WLC. This is very interesting as Azar et al (2018) could not find a relation between FWAs and WLC, adding a major empirical contribution. It can also be imaginable that planning's influence on EE lead to decreased work-life conflicts. It is also likely that there is simply not enough variance in independent and dependent variables in the data set. Planning behavior needs to be inculcated in employee's daily life patterns, which can be done with the help of management by providing workshops (Azar S., 2013). The American Psychological Association's research concludes that health conditions, from obesity to cardiovascular disease and death are associated with constant stress due to work. "Queens School of Business" and "The Gallup Organization" found that stress also leads to disengaged workers causing higher absenteeism, accidents rates and errors, thereby to counter stress-like emotions we use time management skills so that employees feel more in control (Claessens B. J., van Eerde, Rutte, \& Roe, 2007) thus, calling for further research on time planning.

The Dutch Flexible Working Act 2016 (Wet Flexiebel Werken) allows employees the freedom to make demands not only for working hours but also for the schedules to be changed and to work from home. Based on the data of the European Foundation for the Improvement of Living and Working Conditions (2012), more than half of European companies (56 per cent) offer some form of flexible arrangement. The European union (EU) average of flexi-time firms accounts for 56.5 per cent, majority of flexi-time companies operate in Finland (82.8 
percent), the UK (70.8 percent), Denmark (69.4 percent) and Sweden (67.7 percent) (Bajzikova, Sajgalikova, Wojcak, \& Polakova, 2013). Due to the high prevalence of grandparents in households of European countries as studied by Dominik Buttler and Eva Sierminsk (2020), women (especially those with small children) tend to become self-employed based on income trading under more flexible work arrangements this relates to the importance work-life balance. However, financial restrictions have strongly influenced the entry of individuals into starting their own firms (Buttler \& Sierminska, 2020) whereas, in Pakistan majority of the youth invests in acquiring higher level education to find a suitable job, as its people have very limited resources and do not have very good opportunities to build a start-up with the costs being too high.

Evidence from Europe gives us insight on UK's private sector professionals using flexible working arrangements to gain higher level of job satisfaction (Kelliher \& Anderson, 2008). Another recent research shows that Knowledge workers (those who carry out tasks requiring expert thinking and complex communication skills) using flexible arrangements have the chances of being satisfied with job about 72 percent higher than who do not use these arrangements (Viñas-Bardolet, Torrent-Sellens, \& Guillen-Royo, 2020). For future research in Pakistan, it would be interesting to consider how the use of FWA leads to more autonomy and increased management of resources, and its impact on women due to dual responsibilities of practitioners and caregivers, as they are more sensitive to FWA demands.

Recent policy reforms in the United Kingdom also encouraged employers to provide more flexible work arrangements (Chandola, Booker, Kumari, \& Benzeval, 2019). In the absence of legislative controls usage of FWA in Pakistan remain limited while exposure and usage is much more common and embraced in the nations of the European Union. We more than welcome such policy reforms in Pakistan.

\section{Managerial and Policy Implications}

In addition to adding to scientific knowledge, results indicate certain organizational ramifications. FWAs allow privileges for variation of hours/parental leave/telecommuting and do not involve any penalty therefore in demand by employees (Albion, 2004). Often workers are hesitant to make use of these tools if they perceive that they will be regarded adversely by supervisors or if they sense a lack of corporate encouragement, but without usage of FWAs their impact will be minimal. The European Commission policy proposal (2017), asks employers to offer reasons when they refuse flexible work applications, is a positive step in the right direction which other countries should also follow as it protects workers from layoffs and discrimination when using flexible work options. It could also help to allow businesses and managers to realize the true value of flexible work through training campaigns (Chung, 2019). FWA's utilization strategies that organizations adopt depend on that country's institutional context in which the company operates (Kalleberg, 2001). The size of the company also proves to be a considerable factor having significant effect on the adoption of a flexible mode of work. When an organization aims for a competitive position in the market, its workers must adjust their view of work conditions if they want to achieve the objectives set, they are expected to understand the need to change attitudes towards work and behaviour 
(Bajzikova, Sajgalikova, Wojcak, \& Polakova, 2013).

Although our research has its own theoretical implications, it has relevance in countries with collectivistic cultures like Pakistan. Pakistan is seen in terms of traditional domestic roles as a patriarchal society including women abiding by cultural norms (Azar, Khan, \& Eerde, 2018), but women today are playing an increasingly active role in Pakistan's economy, since economic conditions forced women to join the labor force, dual earners are now becoming a usual phenomenon (Nadeem \& Abbas, 2009) as until 2016, female participation rate was $25 \%$ and its rising from then (Asian Development Bank, 2016). FWA research have showed that supervisors and managers must believe in the benefits that FWAs can bring. FWAs demand new ways of thinking about the work being carried out and handled, the position of supervisors becomes increasingly complex but with the easy access to advice and guidance from HR consultants, some of the challenges can be resolved by having clearer views between policy and action (Williams, 2019). This will allow companies to meet the challenges of retaining skilled, hard-working and dedicated workers.

Literature from previous researches show that difficulties arise with the coordination of workers and management of flexible working especially when working in teams. Managers need to encourage workers on using FWA to eliminate any doubts of no career progression (McDonald, Bradley, \& Brown, 2008) (Berkery, Morley, Tiernan, \& Peretz, 2020). For example, initiatives may address the work-life balance of these workers by ensuring greater consistency in work schedules and addressing specific paths for further advancement of career within the organization. Managers must encourage their workers to realize the importance of their company involvement in order to achieve increased organizational commitment and engagement. The more employees feel that they are valued as part of the organization, the more likely they are to remain loyal to the firm. Creating contexts with flexible work options that can enhance the well-being of employees requires attention at the organizational level, with cultural contexts that support both formal and informal implementation, as well as national policies that regulate the conditions under which working hours can and should be open to adjustment. Companies use family-friendly working time strategies to attract employees for strategic purposes like retaining (Ollier-Malaterre, 2009). The practical implications lie in the area of HRD, where measures can be structured to ensure a work-life balance that can lead to a higher engagement of workers and thus a greater commitment towards the organization. Understanding the processes by which companies recognize and grow a dedicated, committed and skilled workforce is essential to future success, not just for the firm, but also for the well-being and prosperity of society.

\section{Conclusion}

Empirical findings showed that workplace engagement, work-life strain and enrichment thoroughly integrated the interaction between flexible job settings and affective organizational commitment. Further, planning actions highlighted the effect of use of FWAs on lowering WLC but did not improve the connection between use of FWAs and employee engagement. Focusing on promoting the use of FWA, management must also work on educating workers to develop patterns in time saving and make the use of FWAs smoother. 


\section{Mll Macrothink}

Human Resource Research

ISSN 1948-5441

2020, Vol. 4, No. 1

Leadership practitioners seek ways to determine employee attachment to the organizations, our results indicate that fruitful commitment can be strengthened by enhancing the working conditions of workers by providing them satisfaction and balance. In addition, it is expected that these results would facilitate more investigations and implementation of family supportive policies in Pakistani organizations.

\section{References}

Aboobaker, N., \& Edward, M. (2017). Work-Family Conflict and Family-Work Conflict Among Employees Across Five Business Sectors in India-Examining The Role of Individual Differences. South Asian Journal of Marketing \& Management Research, 7(2), 24-34. https://doi.org/10.5958/2249-877X.2017.00007.8

Agarwala, T., Arizkuren-Eleta, A., Castillo, E. D., Muñiz-Ferrer, M., \& Gartzia, L. (2014). Influence of managerial support on work-life conflict and organizational commitment: an international comparison for India, Peru and Spain. The International Journal of Human Resource Management, 1460-1483. https://doi.org/10.1080/09585192.2013.870315

Akkermans, J., Schaufeli, W., Brenninkmeijer, V., \& Blonk, R. (2013). The role of career competencies inthe job demands-resources model. Journal of Vocational Behavior, 83, 356 -366. https://doi.org/10.1016/j.jvb.2013.06.011

Albion, M. J. (2004). A measure of attitudes towards flexible work options. Australian Journal of Management, 29(2), 275-294. https://doi.org/10.1177/031289620402900207

Albrecht, S. L. (2015). Challenge demands, hindrance demands and psychological need satisfaction: Their influence on employee engagement and emotional exhaustion. Journal of Personnel Psychology, 14, 70-79. https://doi.org/10.1027/1866-5888/a000122

Albrecht, S. L., \& Marty, A. (2020). Personality, self-efficacy and job resources and their associations with employee engagement, affective commitment and turnover intentions. The International Journal of Human Resource Management, 31(5), 657-681. https://doi.org/10.1080/09585192.2017.1362660

Alis, D. K. (2006). From gods to goddesses. Time and Society, 81-104. https://doi.org/10.1177/0961463X06062280

Allen, N. J., \& Meyer, J. P. (1990). The measurement and antecedents of affective, continuance and normative commitment to the organization. Journal of Occupational Psychology, 1-18. https://doi.org/10.1111/j.2044-8325.1990.tb00506.x

Allen, T. D., Johnson, R. C., Kiburz, K. M., \& Shockley, K. M. (2013). Work-family conflict and flexible work arrangements: Deconstructing flexibility. Personnel Psychology, 66(2), 345-376. https://doi.org/10.1111/peps.12012

Allen, T., Herst, D., Bruck, C., \& Sutton, M. (2000). Consequences associated with work-to-family conflict: A review and agenda for future research. Journal of Occupational Health Psychology, 5, 278-308. https://doi.org/10.1037/1076-8998.5.2.278

Anderson, S. E., Coffey, B. S., \& Byerly, R. T. (2002). Formal organizational initiatives and informal workplace practice: Links to work-family conflict and job-related outcomes. Journal of Management, 173, 1-24. https://doi.org/10.1177/014920630202800605 


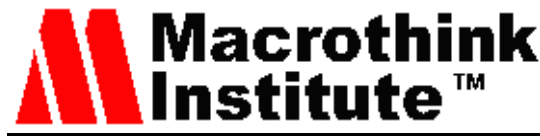

Asian Development Bank. (2016). Female labor force participation in Asia: Keytrends, constraints, and opportunities. Retrieved from https://www.adb.org/sites/default/files/publication/209666/female-labor-force-participation-a sia.pdf

Azar, S. (2013). Impact of time management training on Pakistani corporate sector employees. Journal of Basic and Applied Scientific Research, 3(4), 476-482.

Azar, S., Khan, A., \& Eerde, W. V. (2018). Modelling linkages between flexible work arrangements' use and organizational outcomes. Journal of Business Research, 134-143. https://doi.org/10.1016/j.jbusres.2018.06.004

Babcock-Roberson, M. E., \& Strickland, O. J. (2010). The relationship between charismatic leadership, work engagement, and organizational citizenship behaviors. The Journal of Psychology, 144(3), 313-326. https://doi.org/10.1080/00223981003648336

Bajzikova, L., Sajgalikova, H., Wojcak, E., \& Polakova, M. (2013). Are flexible work arrangements attractive enough for knowledge-intensive businesses? Procedia-Social and Behavioral Sciences, 99, 771-783. https://doi.org/10.1016/j.sbspro.2013.10.549

Bakker, A., \& Demerouti, E. (2007). The job demands-resources model: State of the art. Journal of Managerial Psychology, 22, 309-328. https://doi.org/10.1108/026839407 10733115

Bal, P. M., \& De Lange, A. H. (2015). From flexibility human resource management to employee engagement and perceived job performance across the lifespan: A multisample study. Journal of Occupational and Organizational Psychology, 88(1), 126-154. https://doi.org/10.1111/joop.12082

Balmforth, K., \& Gardner, D. (2006). Conflict and facilitation between work and family. Realizing the outcomes for organizations. New Zealand Journal of Psychology, 35(2), 69-76.

Barnett, R. C., \& Hall, D. T. (2001). How to use reduced hours to win the war for talent. Organizational Dynamics, 29(3), 192-210. https://doi.org/10.1016/S0090-2616(01)00024-9

Baron, R. M., \& Kenny, D. (1986). The moderator-mediator variable distinction in social psychological research: Conceptual, strategic, and statistical considerations. Journal of Personality and Social Psychology, 1173-1182. https://doi.org/10.1037/0022-3514.51.6.1173

Beham, B., Drobnič, S., Präg, P., Baierl, A., \& Lewis, S. (2020). Work-to-family enrichment and gender inequalities in eight European countries. The International Journal of Human Resource Management, 31(5), 589-610. https://doi.org/10.1080/09585192.2017.1355837

Behson, S. (2005). The relative contribution of formal and informal organizational work-family support. Journal of Vocational Behavior, 66, 487-500. https://doi.org/10.1016/j.jvb.2004.02.004

Beigi, M., Shirmohammadi, M., \& Stewart, J. (2018). Flexible work arrangements and work-family conflict: A metasynthesis of qualitative studies among academics . Human Resource Development Review, 17(3), 314-336. https://doi.org/10.1177/1534484318787628

Berkery, E., Morley, M. J., Tiernan, S., \& Peretz, H. (2020). From start to finish: Flexi-time as a social exchange and its impact on organizational outcomes. European Management Journal. https://doi.org/10.1016/j.emj.2020.02.003 
Bhargava, S., \& Baral, R. (2009). Antecedents and Consequences of Work-family Enrichment among Indian Managers. Psychological Studies, 213-225. https://doi.org/10.1007/s12646-009-0028-z

Blau, P. M. (1964). Exchange and power in social life. New York, NY : Wiley.

Bond, S., \& Wise, S. (2003). Family leave policies and devolution to the line. Personnel Review, 32, 58-72. https://doi.org/10.1108/00483480310454727

Budhwar, P., Varma, A., \& Patel, C. (2016). Convergence-divergence of HRM in the Asia-Pacific: Context-specific analysis and future research agenda . Human Resource Management Review, 26(4), 311-326. https://doi.org/10.1016/j.hrmr.2016.04.004

Burke, R. J., \& Cooper, C. L. (2006). Reinventing HRM: Challenges and new directions. London, UK: Routledge. https://doi.org/10.4324/9780203006115

Burke, R. J., \& Ng, E. (2006). The changing nature of work and organizations: Implications for human resource management. Human Resource Management Review, 16(2), 86-94. https://doi.org/10.1016/j.hrmr.2006.03.013

Burud, S., \& Tumolo, M. (2004). Leveraging the New Human Capital: Adaptive Strategies. Results Achieved, and Stories of Transformation. USA: Davies-Black Publishing.

Buttler, D., \& Sierminska, E. (2020). Career or Flexible Work Arrangements? Gender Differences in Self-employment in a Young Market Economy. Journal of Family and Economic Issues. https://oi.org/10.1007/s10834-020-09668-x

Byron, K. (2005). A meta-analytic review of work-family conflict and its antecedents. Journal of vocational behavior, 67(2), 169-198. https://doi.org/10.1016/j.jvb.2004.08.009

Carlson, D. S., Kacmar, K. M., \& Williams, L. J. (2000). Construction and initial validation of a multidimensional measure of work-family conflict. Journal of Vocational Behavior, 249-276. https://doi.org/10.1006/jvbe.1999.1713

Carlson, D., Kacmar, K., Wayne, J., \& Grzywacz, J. (2006). Measuring the positive side of the work-family interface: Development and validation of a work family enrichment scale. Journal of Vocational Behavior, 131-164. https://doi.org/10.1016/j.jvb.2005.02.002

Carmines, E. G., \& Zeller, R. A. (1979). Reliability and Validity Assessment. Sage publication, Inc. https://doi.org/10.4135/9781412985642

Casper, W., Martin, J., Buffardi, L., \& Erdwins, C. (2002). Work-family conflict, perceived organizational support and organizational commitment of working mothers. Journal of Occupational Health Psychology, 7, 99-108. https://doi.org/10.1037/1076-8998.7.2.99

Chan, X. W., Kalliath, T., Brough, P., Siu, O. L., O’Driscoll, M. P., \& Timms, C. (2016). Work-family enrichment and satisfaction: The mediating role of self-efficacy and work-life balance. The International Journal of Human Resource Management, 27(15), 1755-1776. https://doi.org/10.1080/09585192.2015.1075574

Chandola, T., Booker, C. L., Kumari, M., \& Benzeval, M. (2019). Are Flexible Work Arrangements Associated with Lower Levels of Chronic Stress-Related Biomarkers? A Study of 6025 Employees in the UK Household Longitudinal Study. Sociology, 1-21. https://doi.org/10.1177/0038038519826014 


\section{Macrothink}

Human Resource Research

ISSN 1948-5441

2020, Vol. 4, No. 1

Chandra, V. (2012). Work-life balance: Eastern and Western perspectives. The International Journal of Human Resource Management, 23(5), 1040-1056. https://doi.org/10.1080/09585192.2012.651339

Chen, W., Zhang, Y., Sanders, K., \& Xu, S. (2016). Family-friendly work practices and their outcomes in China: The mediating role of work-to-family enrichment and the moderating role of gender. International Journal of Human Resource Management, 1-23. https://doi.org/10.1080/09585192.2016.1195424

Chen, Z., \& Powell, G. (2012). No pain, no gain? A resource-based model of work-to-family enrichment and conflict. Journal of Vocational Behavior, 81, 89-98. https://doi.org/10.1016/j.jvb.2012.05.003

Chin, W. (1998). The Partial least squares approach to structural equation modeling. Mahwah, NJ, US: Lawrence Erlbaum Associates Publishers.

Choo, J. L., Desa, N. M., \& Asaari, M. H. (2016). Flexible Working Arrangement toward Organizational Commitment and Work-Family Conflict. Studies in Asian Social Science, 21.

Chou, K., \& Cheung, K. (2013). Family-friendly policies in the workplace and their effect on work-life conflicts in Hong Kong. International journal of human resource management, Taylor \& Francis. https://doi.org/10.1080/09585192.2013.781529

Chung, H. (2019). 'Women's work penalty'in access to flexible working arrangements across Europe. European Journal of Industrial Relations, 25(1), 23-40. https://doi.org/10.1177/0959680117752829

Claessens, B. J., Van Eerde, W., Rutte, C. G., \& Roe, R. A. (2004). Planning behavior and perceived control of time at work. Journal of Organizational Behavior, 25(8), 937-950. https://doi.org/10.1002/job.292

Claessens, B., van Eerde, W., Rutte, C., \& Roe, R. (2007). A review of the time management literature. Personnel Review, 36(2), 255-276. https://doi.org/10.1108/00483480710726136

Cooke, F. L., Schuler, R., \& Varma, A. (2020). Human resource management research and practice in Asia: Past, present and future . Human Resource Management Review, 100778. https://doi.org/10.1016/j.hrmr.2020.100778

Cotti, C. D., Haley, M. R., \& Miller, L. A. (2014). Workplace flexibilities, job satisfaction and union membership in the US workforce. British Journal of Industrial Relations, 52(3), 403-425. https://doi.org/10.1111/bjir.12025

Cranfield School of Management. (2008). Flexible Working and Performance: Summary of Research. London: Working Families. Cranfield School of Management.

Cropanzano, R., Anthony, E. L., Daniels, S. R., \& Hall, A. V. (2017). Social exchange theory: A critical review with theoretical remedies. Academy of Management Annals, 11(1), 479-516. https://doi.org/10.5465/annals.2015.0099

Crowley, \& Kolenikov. (2014). Flexible work options and mothers' perceptions of career harm. The Sociological Quarterly, Midwest Sociological Society, 168-195. https://doi.org/10.1111/tsq.12050 


\section{$\Lambda$ Macrothink}

Human Resource Research

ISSN 1948-5441

2020, Vol. 4, No. 1

Dancaster, L., \& Baird, M. (2016). Predictors of the adoption of work-care arrangements: A study of South African firms. International Journal of Human Resource Management, 27(4), 456-475. https://doi.org/10.1080/09585192.2015.1042898

De Leede, J., \& Heuver, P. (2017). New ways of working and leadership: an empirical study in the service industry. In J. De Leede, New Ways of Working Practices: Antecedents and Outcomes (pp. 49-71). Bingley: Emerald Group Publishing Limited. https://doi.org/10.1108/S1877-636120160000016004

De Menezes, L. M., \& Kelliher, C. (2017). Flexible working, individual performance, and employee attitudes: Comparing formal and informal arrangements. Human Resource Management, 56(6), 1051-1070. https://doi.org/10.1002/hrm.21822

De Spiegelaere, S., Van Gyes, G., \& Van Hootegem, G. (2016). Not all autonomy is the same. Different dimensions of job autonomy and their relation to work engagement \& innovative work behavior. Human Factors and Ergonomics in Manufacturing \& Service Industries, 26(4), 515-527. https://doi.org/10.1002/hfm.20666

Dettmers, J., Bamberg, E., \& Seffzek, K. (2016). Characteristics of extended availability for work: The role of demands and resources. International Journal of Stress Management, 23(3), 276. https://doi.org/10.1037/str0000014

Douglas, H. E., Bore, M., \& Munro, D. (2016). Coping with university education: The relationships of time management behaviour and work engagement with the five factor model aspects. Learning and Individual Differences, 45, 268-274. https://doi.org/10.1016/j.lindif.2015.12.004

Duxbury, L., Higgins, C., \& Schroeder, B. (2009). Balancing Paid Work and Caregiving Responsibilities: A Closer Look at Family Caregivers in Canada. Ottawa: Canadian Policy Research Networks.

Eby, L., Casper, W., Lockwood, A., Bordeaux, C., \& Brinley, A. (2005). Work and family research in IO/OB: content analysis and review of the literature (1989-2002). Journal of Vocational Behavior, 66, 124-197. https://doi.org/10.1016/j.jvb.2003.11.003

Erden Bayazit, Z., \& Bayazit, M. (2019). How do flexible work arrangements alleviate work-family-conflict? The roles of flexibility i-deals and family-supportive cultures . The International Journal of Human Resource Management, 405-435. https://doi.org/10.1080/09585192.2017.1278615

Fahlén, S. (2016). Equality at home - A question of career? Housework, norms, and policies in a European comparative perspective . Demographic Research, 35, 1411-1440. https://doi.org/10.4054/DemRes.2016.35.48

Fornell, C., \& Larcker, D. (1981). Evaluating structural equation models with unobservable variables and measurement error. Journal of Marketing Research, 39-50. https://doi.org/10.1177/002224378101800104

Frank, F., Finnegan, R., \& Taylor, C. (2004 ). The race for talent: retaining and engaging workers in the 21 st century. Human Resource Planning, 12-25.

Frost, J. D. (2017). How to interpret $R$-squared in regression analysis. Retrieved from Statistics By Jim: https://statisticsbyjim.com/regression/interpret-r-squared-regression/ 


\section{I Macrothink}

Galea, C., Houkes, I., \& De Rijk, A. (2014). An insider's point of view: how a system of flexible working hours helps employees to strike a proper balance between work and personal life. The International Journal of Human Resource Management, 25(8), 1090-1111. https://doi.org/10.1080/09585192.2013.816862

Gerards, R., de Grip, A., \& Baudewijns, C. (2018). Do new ways of working increase work engagement? Personnel Review, 47, 517-534. https://doi.org/10.1108/PR-02-2017-0050

Glass, J. L., \& Finley, A. (2002). Coverage and effectiveness of family-responsive workplace policies . Human resource management review, 12(3), 313-337. https://doi.org/10.1016/S1053-4822(02)00063-3

Gold, M., \& Mustafa, M. (2013). "Work always wins": Client colonisation, time management and the anxieties of connected freelancers. New Technology, Work and Employment, 28(3), 197-211. https://doi.org/10.1111/ntwe.12017

Golden, L. (2001). Flexible work schedules. Which workers get them? American Behavioral Scientist, 44(7), 1157-1178. https://doi.org/10.1177/00027640121956700

Golden, L., Sweet, S., \& Chung, H. (2018). Positive and negative application of flexible working time arrangements: comparing the United States of America and the EU countries. In Handbook of Research on Comparative Human Resource Management. Edward Elgar. https://doi.org/10.4337/9781784711139.00020

Gould-Williams, J. (2007). HR practices, organizational climate and employee outcomes: evaluating social exchange relationships in local government. The International Journal of Human Resource Management, 18(9), 1627-1647. https://doi.org/10.1080/09585190701570700

Greenhaus, J. H., \& Powell, G. N. (2006). When work and family are allies: A theory of workfamily enrichment. Academy of Management Review, 31, 72-92. https://doi.org/10.5465/amr.2006.19379625

Haar, J. M. (2013). Testing a new measure of work-life balance: A study of parent and nonparent employees from New Zealand. The International Journal of Human Resource Management, 24, 3305-3324.

Haar, J., \& Bardoel, E. (2008). Positive spillover from the work-to-family interface: A study of Australian employees. Asia Pacific Journal of Human Resources, 46(3), 275-287.

Hair, J. F. (2010). Mutilvariate data analysis (7th ed.). Upper Saddle River, NJ: Pearson Prentice Hall, 280.

Hair, J. F., Matthews, L. M., Matthews, R. M., \& Sarstedt, M. (2017). PLS-SEM or CB-SEM: updated guidelines on which method to use. Int. J. Multivariate Data Analysis, 107-123. doi:https://doi.org/10.1504/IJMDA.2017.10008574

Halbesleben, J. R., Neveu, J. P., Paustian-Underdahl, S. C., \& Westman, M. (2014). Getting to the "COR" understanding the role of resources in conservation of resources theory. Journal of Management, 40(5), 1334-1364. https://doi.org/10.1177/0149206314527130

Hammer, L. B., Neal, M. B., Newsom, J. T., Brockwood, K. J., \& Colton, C. L. (2005). A longitudinal study of the effects of dual-earner couples' utilization of family-friendly 


\section{Macrothink}

workplace supports on work and family outcomes. Journal of Applied Psychology, 90(4), 799. https://doi.org/10.1037/0021-9010.90.4.799

Harter, J. K., Schmidt, F. L., \& Hayes, T. L. (2002). Business-unit-level relationship between employee satisfaction, employee engagement, and business outcomes: A meta- analysis. Journal of Applied Psychology, 87(2), 268-279. https://doi.org/10.1037/0021-9010.87.2.268

Hayes, A. F. (2013). Introduction to mediation, moderation, and conditional process analysis: A regression-based approach. New York, US: Guilford Press.

Heerwagen, J. K. (2010). The changing nature of organizations, work, and workplace. National Institute of Building Sciences, 1-13.

Herrbach, O., Mignonac, K., Vandenberghe, C., \& Negrini, A. (2009). Perceived HRM practices, organizational commitment, and voluntary early retirement among late-career managers. Human Resource Management, 48(6), 895-915. https://doi.org/10.1002/hrm.20321

Hill, E. J. (2005). Work-to-family facilitation and confl ict, working fathers and mothers, work-to-family stressors and support. Journal of Family Issues, 793-819. https://doi.org/10.1177/0192513X05277542

Hill, E. J., Yang, C., Hawkins, A. J., \& Ferris, M. (2004). A cross-cultural test of the work-family interface in 48 countries. Journal of Marriage and Family, 66, 1300-1316. https://doi.org/10.1111/j.0022-2445.2004.00094.x

Hill, E., Grzywacz, J., Allen, S., Blanchard, V., Matz-Costa, C., Shulkin, S., \& Pitt-Catsouphes, M. (2008). Defining and conceptualizing workplace flexibility. Community, Work \& Family, 11(2), 149-163.

Kalleberg, A. (2001). Organizing flexibility: The flexible firm in a new century. British Journal of Industrial relations, 479-504.

Kaufman, B. E. (2010). SHRM theory in the post-huselid era: Why it is fundamentally $\begin{array}{llll}\text { misspecified. Industrial } & \text { Relations, } & \text { 49(2), }\end{array}$ https://doi.org/10.1111/j.1468-232X.2009.00600.x

Kelliher, C., \& Anderson, D. (2008). For better or for worse? An analysis of how flexible working practices influence employees' perceptions of job quality. International Journal of Human Resource Management, 419-431. https://doi.org/10.1080/09585190801895502

Kelliher, C., Richardson, J., \& Boiarintseva, G. (2019). All of work? All of life? Reconceptualising work-life balance for the 21 st century . Human Resource Management Journal, 29(2), 97-112. https://doi.org/10.1111/1748-8583.12215

Ketchand, A. A., \& Strawser, J. R. (2001). Multiple dimensions of organizational commitment: Implications for future accounting research. Behavioral Research in Accounting, 13, 221-251.

Kim, K. Y., Eisenberger, R., \& Baik, K. (2016). Perceived organizational support and affective organizational commitment: Moderating influence of perceived organizational competence. Journal of Organizational Behavior, 37, 558-583. https://doi.org/10.1002/job.2081 


\section{Ml Macrothink}

Human Resource Research

ISSN 1948-5441

2020, Vol. 4, No. 1

Kingma, S. (2019). New ways of working (NWW): work space and cultural change in virtualizing organizations. Culture and Organization, 25(5), 383-406. https://doi.org/10.1080/14759551.2018.1427747

Kock, N. (2015). Common method bias in PLS-SEM: A full collinearity assessment approach. International Journal of e-Collaboration, $11(4), \quad 1-10$. https://doi.org/10.4018/ijec.2015100101

Kooij, D., \& Van de Voorde, K. (2011). How changes in subjective general health predict future time perspective, and development and generativity motives over the lifespan. Journal of Occupational and Organizational Psychology, 84, 247. https://doi.org/10.1111/j.2044-8325.2010.02012.x

Kossek, E. E., \& Lautsch, B. A. (2012). Work-family boundary management styles in organizations: A cross-level model . Organizational Psychology Review, 2, 152-171. https://doi.org/10.1177/2041386611436264

Lambert, E. G., Liu, J., Jiang, S., Kelley, T. M., \& Zhang, J. (2020). Examining the association between work-family conflict and the work attitudes of job satisfaction and organizational commitment among Chinese correctional staff. Psychiatry, Psychology and Law , 1-20. https://doi.org/10.1080/13218719.2020.1734980

Lambert, L. S., Bingham, J. B., \& Zabinski, A. (2020). Affective commitment, trust, and the psychological contract: contributions matter, too! European Journal of Work and $\begin{array}{lll}\text { Organizational Psychology, 29(2), } & \text { 294-314. }\end{array}$ https://doi.org/10.1080/1359432X.2019.1697743

Lapierre, L. M., \& Allen, T. D. (2012). Control at work, control at home, and planning behavior: Implications for work-family conflict. Journal of Management, 38(5), 1500-1516. https://doi.org/10.1177/0149206310385868

Lapierre, L., \& Allen, T. (2006). Work-supportive family, family-supportive supervision, use of organizational benefits and problem-focused coping: implications for work- family conflict and employee well-being. Journal of Occupational Health Psychology, 11, 169-181. https://doi.org/10.1037/1076-8998.11.2.169

Le, H., Newman, A., Menzies, J., Zheng, C., \& Fermelis, J. (2020). Work-life balance in Asia: A systematic review . Human Resource Management Review, 100766. https://doi.org/10.1016/j.hrmr.2020.100766

Lewis, S., Smithson, J., Cooper, C. L., \& Dyer, J. (2002). Flexible Futures: Flexible Working and Work-Life Integration (Report on Phase Two). London: Institute of Chartered Accountants in England and Wales.

Lufkin, B. (2020, March 13). Coronavirus: How to work from home, the right way. Retrieved from

BBC:

https://www.bbc.com/worklife/article/20200312-coronavirus-covid-19-update-work-from-ho me-in-a-pandemic

Macan, T. (1994). Time management: Test of a process model. Journal of Applied Psychology, 79, 381-391. https://doi.org/10.1037/0021-9010.79.3.381 


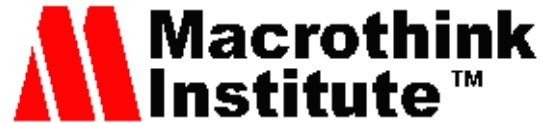

Macan, T., Shahani, C., Dipboye, R. L., \& Phillips, A. P. (1990). College students' time management: Correlations with academic performance and stress. Journal of Educational Psychology, 82, 760-768. https://doi.org/10.1037/0022-0663.82.4.760

Mackey, A., \& Gass, S. M. (2015). Second language research: Methodology and design. Routledge. https://doi.org/10.4324/9781315750606

Maden, C. (2015). "Linking high involvement human resource practices to employee proactivity: the role of work engagement and learning goal orientation". Personnel Review, 44(5), 720-738 . https://doi.org/10.1108/PR-01-2014-0030

Madsen, S. (2006). Work and family conflict: can home based teleworking make a difference? International Journal of Organization Theory and Behavior, 9, 307-350. https://doi.org/10.1108/IJOTB-09-03-2006-B002

Madsen, S., John, C., \& Miller, D. (2005). 'Work-Family Conflict and Health: A Study of Workplace, Psychological, and Behavioral Correlates. Journal of Behavioral and Applied Management, 6, 225-247. https://doi.org/10.21818/001c.14555

Masuda, A. D., Poelmans, S. A., Allen, T. D., Spector, P. E., Lapierre, L. M., Cooper, C. L., \& Moreno-Velazquez, I. (2012). Flexible work arrangements availability and their relationship with work-to-family conflict, job satisfaction, and turnover intentions: A comparison of three country clusters. Applied Psychology, 61(1), 1-29. https://doi.org/10.1111/j.1464-0597.2011.00453.x

Matthews, R., Barnes-Farrell, J., \& Bulger, C. (2010). Advancing measurement of work and family domain boundary characteristics. Journal of Vocational Behavior, 77, 447-460. https://doi.org/10.1016/j.jvb.2010.05.008

Maxwell, G., Rankine, L., Bell, S., \& MacVicar, A. (2007). The incidence and impact of flexible working arrangements in smaller businesses. Employee Relations, 29, 138-152. https://doi.org/10.1108/01425450710719987

McDonald, P., Bradley, L., \& Brown, K. (2008). Visibility in the workplace: still an essential ingredient for career success? The International Journal of Human Resource Management, 19(12), 2198-2215. https://doi.org/10.1080/09585190802479447

McMillan, H. S., Morris, M. L., \& Atchley, E. K. (2011). Constructs of the work/life interface: A synthesis of the literature and introduction of the concept of work/life harmony. Human Resource Development Review, 10, 6-25. https://doi.org/10.1177/1534484310384958

McNall, L. A., Masuda, A. D., \& Nicklin, J. M. (2010). Flexible work arrangements, job satisfaction, and turnover intentions: The me diating role of work-to-family enrichment. The Journal of Psychology, 61-81. https://doi.org/10.1080/00223980903356073

McNall, L. A., Nicklin, J. M., \& Masuda, A. D. (2010). A meta-analytic review of the consequences associated with work-family enrichment. Journal of Business Psychology, 25, 381-396. https://doi.org/10.1007/s10869-009-9141-1

Mello, J. A. (2019). Strategic human resource management. Boston, MA: Cengage.

Menguc, B., Auh, S., Fisher, M., \& Haddad, A. (2013). To be engaged or not to be engaged: The antecedents and consequences of service employee engagement. Journal of Business Research, 66, 2163-2170. https://doi.org/10.1016/j.jbusres.2012.01.007 


\section{Macrothink}

Human Resource Research

ISSN 1948-5441

2020, Vol. 4, No. 1

Meyer, J. P., \& Allen, N. J. (1991). A three-component conceptualization of organizational commitment. Human Resource Management Review, 1, 61-89. https://doi.org/10.1016/1053-4822(91)90011-Z

Meyer, J. P., \& Allen, N. J. (1997). Commitment in the workplace: Theory, research, and application. Newbury Park, CA: Sage.

Meyer, J. P., \& Herscovitch, L. (2001). Commitment in the workplace: Toward a general model. Human Resource Management Review, 11, 299-326. https://doi.org/10.1016/S1053-4822(00)00053-X

Meyer, J. P., Stanley, D. J., Herscovitch, L., \& Topolnytsky, L. (2002). Affective, continuance, and normative commitment to the organization: A meta-analysis of antecedents, correlates, and consequences. Journal of Vocational Behavior, 61, 20-52. https://doi.org/10.1006/jvbe.2001.1842

Michel, J., Daniel, R., \& Eduardo, C. (2015). Work Schedule Flexibility, Work-Family Enrichment and Job Satisfaction. Journal of Behavioural Sciences, 78-90.

Nadeem, M., \& Abbas, D. (2009). The impact of work life conflict on job satisfactions of employees in Pakistan. International Journal of Business and Management, 4(2), 63-83. https://doi.org/10.5539/ijbm.v4n5p63

Nahrgang, J., Morgeson, F., \& Hofmann, D. (2011). "Safety at work: a meta-analytic investigation of the link between job demands, job resources, burnout, engagement, and safety outcomes" . Journal of Applied Psychology, 71-95. https://doi.org/10.1037/a0021484

Odle-Dusseau, H. N., Britt, T. W., \& Greene-Shortridge, T. M. (2012). Organizational work-family resources as predictors of job performance and attitudes: The process of work-family conflict and enrichment. Journal of Occupational Health Psychology, 17, 28-40. https://doi.org/10.1037/a0026428

Ollier-Malaterre, A. (2009). Organizational work-life initiatives: context matters: France compared to the UK and the US. Community, Work and Family, 12(2), 159-178. https://doi.org/10.1080/13668800902778942

Parkes, L. P., \& Langford, P. H. (2008). Work-life balance or work-life alignment? A test of the importance of work-life balance for employee engagement and intention to stay in organisations. Journal of Management \& Organization, 14(3), 267-284. https://doi.org/10.1017/S1833367200003278

Parry, E., \& Urwin, P. (2011). Generational Differences in Work Values: A Review of Theory and Evidence. International Journal of Management Reviews, 13, 79-96. https://doi.org/10.1111/j.1468-2370.2010.00285.x

Peters, P., Poutsma, E., Vander Heijden, B., Bakker, A., \& Bruijn, T. (2014). Enjoying new ways to work: an HRM-process approach to study flow. Human Resource Management, 271-290. https://doi.org/10.1002/hrm.21588

Poon, J. (2013). "Relationships among perceived career support, affective commitment, and work engagement". International Journal of Psychology, 1148-1155. https://doi.org/10.1080/00207594.2013.768768 


\section{Macrothink}

Human Resource Research

ISSN 1948-5441

2020, Vol. 4, No. 1

Porter, L. W., Mowday, R. T., \& Steers, R. M. (1979). The measurement of organizational commitment. Journal of vocational behavior, 14(2), 224-247. https://doi.org/10.1016/0001-8791(79)90072-1

Ramakrishnan, S., \& Arokiasamy, L. (2019). Flexible Working Arrangements in Malaysia; a Study of Employee's Performance on White Collar Employees . Global Business and Management Research, 11(1), 551-559.

Rhoades, L., Eisenberger, R., \& Armeli, S. (2001). 'Affective Commitment to the Organization: The Contribution of Perceived Organizational Support. Journal of Applied Psychology, 86, 825-836. https://doi.org/10.1037/0021-9010.86.5.825

Richman, A. (2006). Everyone wants an engaged workforce how can you create it? Workspan, 36-9.

Richman, A. L., Civian, J. T., Shannon, L. L., Jeffrey Hill, E., \& Brennan, R. T. (2008). The relationship of perceived flexibility, supportive work-life policies, and use of formal flexible arrangements and occasional flexibility to employee engagement and expected retention. Community, work and family, 11(2), 183-197. https://doi.org/10.1080/13668800802050350

Ronen, S. (1981). Flexible working hours: An innovation in the quality of work life. New York, NY: McGraw-Hill Companies.

Rupp, D. E., \& Cropanzano, R. (2002). The mediating effects of social exchange relationships in predicting workplace outcomes from multifoci organizational justice. Organizational Behavior and Human Decision Processes, 89(1), 925-946. https://doi.org/10.1016/S0749-5978(02)00036-5

Ryan, R., \& Deci, E. (2001). On happiness and human potentials: A review of research on hedonic and eudaimonic well-being. Annual Review of Psychology, 52, 139-170. https://doi.org/10.1146/annurev.psych.52.1.141

Saks, A. M. (2006). Antecedents and consequences of employee engagement. Journal of Managerial Psychology, 21(7), 600-619. https://doi.org/10.1108/02683940610690169

Schaufeli, W. B., \& Bakker, A. B. (2004). Job demands, job resources, and their relationship with burnout and engagement: A multi-sample study. Journal of Organizational Behavior, 25(3), 293-315.

Schaufeli, W., \& Bakker, A. (2003). Test manual for the Utrecht Work Engagement Scale. Unpublished manuscript, Utrecht University, the Netherlands, Retrieved from http://www.schaufeli.com.

Schaufeli, W., Salanova, M., González-Romá, V., \& Bakker, A. (2002). “The measurement of engagement and burnout: a two sample confirmatory factor analytic approach". Journal of Happiness Studies, 71-92. https://doi.org/10.1023/A:1015630930326

Seppälä, E., \& Cameron, K. (2015, December 1). Proof That Positive Work Cultures Are More Productive. Retrieved from Harvard business review: https://hbr.org/2015/12/proof-that-positive-work-cultures-are-more-productive

Shaw, K. (2005). An engagement strategy process for communicators. Strategic Communication Management, 26-9. 


\section{MInstitute Macrothink $_{\text {Int }}$}

Human Resource Research

ISSN 1948-5441

2020, Vol. 4, No. 1

Shook, C. L., Ketchen, D. J., Hult, G. T., \& Kacmar, K. M. (2004). Research notes and commentaries: An assessment of the use of structural equation modeling in strategic management research. Strategic Management Journal, 397-404. https://doi.org/10.1002/smj.385

Shrout, P. E., \& Bolger, N. (2002). Mediation in Experimental and Nonexperimental Studies: New Procedures and Recommendations. The American Psychological Association, 422-445. https://doi.org/10.1037/1082-989X.7.4.422

Shuck, B., \& Wollard, K. (2010). Employee engagement and HRD: A seminal review of the foundations. Human Resource Development Review, 9(1), 89-110. https://doi.org/10.1177/1534484309353560

Siu, O., Lu, J., Brough, P., Lu, C., Bakker, A., Kalliath, T., . . O’Driscoll, M. (2010). Role resources and work-family enrichment: The role of work engagement . Journal of Vocational Behavior, 470-480. https://doi.org/10.1016/j.jvb.2010.06.007

Society of human resource management. (2010, September 23). SHRM Executive Roundtable on Workplace Flexibility. Retrieved from shrm.org: https://blog.shrm.org/sites/default/files/reports/11-0013\%20ExecRoundtableWorkFlex_FINA L.pdf

Sonnentag, S. (2012). Time in organizational research: Catching up on a long neglected topic in order to improve theory. Organizational Psychology Review, 2, 361-368. https://doi.org/10.1177/2041386612442079

Spurk, D., \& Straub, C. (2020). Flexible employment relationships and careers in times of the COVID-19 pandemic. Journal of Vocational Behavior. https://doi.org/10.1016/j.jvb.2020.103435

Stairs, M. (2005). Work happy: Developing employee engagement to deliver competitive advantage. Selection and Development Review, 21(5), 7.

Stavrou, E. T., Casper, W. J., \& Lerodiakonou, C. (2015). Support for part-time work as a channel to female employment: The moderating effects of national gender empowerment and labour market conditions. The International Journal of Human Resource Management , 26, 688-706. https://doi.org/10.1080/09585192.2014.971847

Streich, M., Casper, W. J., \& Salvaggio, A. N. (2008). Examining couples' agreement about work-family conflict. Journal of Managerial Psychology, 23, 252-272. https://doi.org/10.1108/02683940810861374

Streukens, S., \& Werelds, S. (2016). Bootstrapping and PLS-SEM: A step-by-step guide to get more out of your bootstrap results. European Management Journal, 1-15. https://doi.org/10.1016/j.emj.2016.06.003

Talukder, A. M. (2019). Supervisor support and organizational commitment: The role of work-family conflict, job satisfaction, and work-life balance . Journal of Employment Counseling, 56(3), 98-116. https://doi.org/10.1002/joec.12125

Teasdale. (2013). Fragmented sisters? The implications of flexible working policies for professional women's workplace relationships. Gender, Work and Organization, 20(4), 397-412. https://doi.org/10.1111/j.1468-0432.2012.00590.x 


\section{Macrothink}

Human Resource Research

ISSN 1948-5441

2020, Vol. 4, No. 1

Ter Hoeven, C. L., \& Van Zoonen, W. (2020). Helping others and feeling engaged in the context of workplace flexibility: The importance of communication control. International journal of business communication, 2329488419898799. https://doi.org/10.1177/2329488419898799

Tims, M., Bakker, A. B., Derks, D., \& Van Rhenen, W. (2013). Job crafting at the team and individual level: Implications for work engagement and performance. Group \& Organization Management, 38, 427-454. https://doi.org/10.1177/1059601113492421

Tims, M., Bakker, A., \& Derks, D. (2014). Daily job crafting and the self-efficacy Performance relationship. . Journal of Managerial Psychology, 29(5), 490-507. https://doi.org/10.1108/JMP-05-2012-0148

Tongco, M. D. (2007). Purposive sampling as a tool for informant selection. Ethnobotany Research and applications, 5, 147-158. https://doi.org/10.17348/era.5.0.147-158

Truss, C., Mankin, D., \& Kelliher, C. (2012). Strategic Human Resource Management. New York: Oxford University Press.

Truss, C., Shantz, A., Soane, E., Alfes, K., \& Delbridge, R. (2013). Employee engage ment, organisational performance and individual well-being: Exploring the evidence, developing the theory. The International Journal of Human Resource Management, 24(14), 2657-2699. https://doi.org/10.1080/09585192.2013.798921

Viñas-Bardolet, C., Torrent-Sellens, J., \& Guillen-Royo, M. (2020). Knowledge workers and job satisfaction: evidence from Europe. Journal of the Knowledge Economy, 11(1), 256-280. https://doi.org/10.1007/s13132-018-0541-1

Vuori, J., Toppinen-Tanner, S., \& Mutanen, P. (2011). Effects of resourcebuilding group intervention on career management and mental health in work organizations: Randomized controlled field trial. Journal of Applied Psychology, 97, 273-286. https://doi.org/10.1037/a0025584

Vyas, L., Lee, S. Y., \& Chou, K. L. (2017). Utilization of family-friendly policies in Hong Kong. International Journal of Human Resource Management, 28(20), 2893-2915. https://doi.org/10.1080/09585192.2016.1138498

Wayne, J. H., Casper, W. J., Matthews, R. A., \& Allen, T. D. (2013). Family-supportive organization perceptions and organizational commitment: The mediating role of work-family conflict and enrichment and partner attitudes . Journal of Applied Psychology, 98(4), 606. https://doi.org/10.1037/a0032491

Wayne, J., Randel, A., \& Stevens, J. (2006). The role of identity and work-to-family support in work-to-family enrichment and its work-related consequences. Journal of Vocational Behavior, 69(3), 445-461. https://doi.org/10.1016/j.jvb.2006.07.002

Weer, C. H., \& Greenhaus, J. H. (2020). Managers' assessments of employees' organizational career growth opportunities: The role of extra-role performance, work engagement, and perceived organizational commitment. Journal of Career Development, 47(3), 280-295. https://doi.org/10.1177/0894845317714892 
Werbel, J., \& Walter, M. (2002). Changing view of work and family roles: A. symbiotic Perspective. Human Resource Management Review, 12(3), 293-298. https://doi.org/10.1016/S1053-4822(02)00061-X

Williams, P. (2019). Support for supervisors: HR enabling flexible work. Employee Relations: The International Journal. https://doi.org/10.1108/ER-03-2018-0077

Wong, K. K.-K. (2013). Partial Least Squares Structural Equation Modeling (PLS-SEM) Techniques Using SmartPLS . Marketing Bulletin, 22.

Zhang, M., Griffeth, R., \& Fried, D. (2012). 'Work-Family Conflict and Individual Consequences. Journal of Managerial Psychology, 27, 696-713. https://doi.org/10.1108/02683941211259520

Zou, K. H., Tuncali, K., \& Silverman, S. G. (2003). Correlation and simple linear regression. . Radiology, 227(3), 617-628. https://doi.org/10.1148/radiol.2273011499

\section{Appendix}

Appendix 1. shows table 3 (Descriptive statistics): Mean, standard deviation (SD) and confirmatory factor analysis (CFA) along with the survey questions.

\begin{tabular}{|c|c|c|c|c|c|c|}
\hline \multirow{2}{*}{ VARIABLE } & \multirow{2}{*}{ QUESTIONS } & \multicolumn{2}{|c|}{$\begin{array}{l}\text { DESCRIPTIVE } \\
\text { STATISTICS }\end{array}$} & \multicolumn{3}{|c|}{$\begin{array}{l}\text { CONFIRMATORY } \\
\text { FACTOR ANALYSIS } \\
\text { (CFA) }\end{array}$} \\
\hline & & Mean & SD & $\begin{array}{l}\text { Outer } \\
\text { loading }\end{array}$ & $\begin{array}{l}\mathbf{T} \\
\text { Stats }\end{array}$ & $\begin{array}{l}\mathbf{P} \\
\text { Value }\end{array}$ \\
\hline \multirow{5}{*}{$\stackrel{\circlearrowright}{\ell}$} & $\begin{array}{l}\text { 1. I would be pleased to remain in } \\
\text { this organization for the rest of my } \\
\text { career. }\end{array}$ & 3.817 & 1.156 & 0.831 & 32.072 & 0.000 \\
\hline & $\begin{array}{l}\text { 2. I feel like the issues of this } \\
\text { company are my own. }\end{array}$ & 3.927 & 1.027 & 0.860 & 46.967 & 0.000 \\
\hline & $\begin{array}{l}\text { 3. I feel deeply committed to this } \\
\text { organization. }\end{array}$ & 3.947 & 1.054 & 0.856 & 47.035 & 0.000 \\
\hline & $\begin{array}{l}\text { 4. To me, my company has a great } \\
\text { deal of personal meaning. }\end{array}$ & 3.923 & 1.070 & 0.896 & 70.857 & 0.000 \\
\hline & $\begin{array}{l}\text { 5. I have a deep sense of belonging } \\
\text { towards this organization. }\end{array}$ & 4.010 & 1.002 & 0.887 & 63.491 & 0.000 \\
\hline$\sum_{i}^{\longleftarrow}$ & $\begin{array}{l}\text { 1. How much flexibility do you } \\
\text { have in arranging your hours of } \\
\text { work that is, how much flexibility }\end{array}$ & 5.343 & 1.604 & 0.852 & 39.502 & 0.000 \\
\hline
\end{tabular}




\section{Macrothink $\Delta$ Institute ${ }^{\text {mk }}$}

\begin{tabular}{|c|c|c|c|c|c|c|}
\hline & $\begin{array}{l}\text { do you have in setting the time you } \\
\text { arrive at work and leave every day? }\end{array}$ & & & & & \\
\hline & $\begin{array}{l}\text { 2. How much flexibility do you } \\
\text { have over the number of hours you } \\
\text { work, such as being able to work } \\
\text { part-time when you are full-time } \\
\text { employee or vice-versa? }\end{array}$ & 5.277 & 1.701 & 0.872 & 45.592 & 0.000 \\
\hline & $\begin{array}{l}\text { 3. Few individuals are forced to } \\
\text { work at one employer-specific } \\
\text { location, and others have an option } \\
\text { to work at different location, or at } \\
\text { home. With that in mind, how much } \\
\text { power do you have over where } \\
\text { you're working? }\end{array}$ & 5.240 & 1.780 & 0.848 & 40.094 & 0.000 \\
\hline & $\begin{array}{l}\text { 4. Events in life are unexpected and } \\
\text { cannot be scheduled, such as sudden } \\
\text { sickness or an emergency. How } \\
\text { much flexibility do you have over a } \\
\text { short-term period to meet such } \\
\text { unforeseeable needs? }\end{array}$ & 5.493 & 1.427 & 0.816 & 33.744 & 0.000 \\
\hline & $\begin{array}{l}\text { 5. Some events are part of daily } \\
\text { routine, such as going to university, } \\
\text { attending lessons, or volunteering } \\
\text { for community. How much } \\
\text { flexibility do you have over some } \\
\text { time off from work to do these kinds } \\
\text { of routinely occurring things? }\end{array}$ & 5.527 & 1.425 & 0.873 & 59.074 & 0.000 \\
\hline & $\begin{array}{l}\text { 6. Many things in life are time } \\
\text { taking, such as taking care of a } \\
\text { newborn, having a serious health } \\
\text { condition, or caring for a family } \\
\text { member with some serious health } \\
\text { condition. How much control do } \\
\text { you have over short-term or longer } \\
\text { working time? }\end{array}$ & 5.467 & 1.486 & 0.854 & 53.424 & 0.000 \\
\hline 2 & $\begin{array}{l}\text { 1. My involvement in the job makes } \\
\text { me consider multiple viewpoints, } \\
\text { and it allows me to be a stronger } \\
\text { family member. }\end{array}$ & 3.967 & 0.937 & 0.860 & 49.995 & 0.000 \\
\hline & $\begin{array}{l}\text { 2. The engagement in the job makes } \\
\text { me feel emotionally satisfied, and it }\end{array}$ & 3.937 & 0.916 & 0.836 & 38.371 & 0.000 \\
\hline
\end{tabular}




\section{MInstitute ${ }^{\text {Macrothink }}$}

Human Resource Research

ISSN 1948-5441

2020, Vol. 4, No. 1

\begin{tabular}{|c|c|c|c|c|c|c|}
\hline & $\begin{array}{l}\text { allows me to be a better family } \\
\text { member. }\end{array}$ & & & & & \\
\hline & $\begin{array}{l}\text { 3. My participation in the job gives } \\
\text { me a sense of accomplishment, and } \\
\text { that allows me to be a better family } \\
\text { member. }\end{array}$ & 3.953 & 0.886 & 0.832 & 36.798 & 0.000 \\
\hline & $\begin{array}{l}\text { 4. My presence in my family puts } \\
\text { me in a good mood, and that allows } \\
\text { me to be a better person at work. }\end{array}$ & 3.997 & 0.881 & 0.821 & 39.381 & 0.000 \\
\hline & $\begin{array}{l}\text { 5. My participation in my family } \\
\text { allows me to use my work time in a } \\
\text { concentrated way, and this helps me } \\
\text { to be a better worker. }\end{array}$ & 4.077 & 0.889 & 0.772 & 23.609 & 0.000 \\
\hline \multirow{5}{*}{ 되디 } & $\begin{array}{l}\text { 1. I find the work I do to be } \\
\text { meaningful and valuable. }\end{array}$ & 4.553 & 1.327 & 0.829 & 36.174 & 0.000 \\
\hline & $\begin{array}{l}\text { 2. I feel like going to work when I } \\
\text { get up in the morning. }\end{array}$ & 4.403 & 1.523 & 0.830 & 38.275 & 0.000 \\
\hline & 3. When I work, I get carried away. & 4.527 & 1.343 & 0.834 & 39.253 & 0.000 \\
\hline & 4. When I work, time flies. & 4.720 & 1.203 & 0.749 & 22.705 & 0.000 \\
\hline & $\begin{array}{l}\text { 5. I persevere in my work, even } \\
\text { though things go unwell. }\end{array}$ & 4.683 & 1.212 & 0.822 & 34.678 & 0.000 \\
\hline \multirow{5}{*}{ ב } & $\begin{array}{l}\text { 1. My work keeps me away from } \\
\text { my family activities more than I } \\
\text { would want. }\end{array}$ & 2.303 & 1.264 & 0.899 & 58.636 & 0.000 \\
\hline & $\begin{array}{l}\text { 2. The time I must dedicate to my } \\
\text { job keeps me from participating } \\
\text { equally in household responsibilities } \\
\text { and activities. }\end{array}$ & 2.317 & 1.245 & 0.907 & 59.887 & 0.000 \\
\hline & $\begin{array}{l}\text { 3. I skip family events because of } \\
\text { the amount of time I have to spend } \\
\text { on work obligations. }\end{array}$ & 2.283 & 1.277 & 0.925 & 89.724 & 0.000 \\
\hline & $\begin{array}{l}\text { 4. Sometimes, I'm so } \\
\text { physically/emotionally exhausted } \\
\text { that I can't spend time with my } \\
\text { family. }\end{array}$ & 2.320 & 1.259 & 0.924 & 99.400 & 0.000 \\
\hline & $\begin{array}{l}\text { 5. Once I get home from work, I am } \\
\text { too overwhelmed to take part in } \\
\text { family activities/responsibilities. }\end{array}$ & 2.303 & 1.311 & 0.896 & 51.136 & 0.000 \\
\hline
\end{tabular}




\begin{tabular}{|l|l|l|l|l|l|l|}
\hline \multirow{2}{*}{} & 1. I have set short-term targets. & 3.903 & 0.997 & 0.737 & 15.928 & 0.000 \\
\cline { 2 - 7 } & 2. I feel in control of my time. & 3.933 & 1.031 & 0.848 & 45.095 & 0.000 \\
\cline { 2 - 7 } & 3. I give priority to my tasks. & 4.153 & 0.839 & 0.805 & 30.470 & 0.000 \\
\cline { 2 - 7 } & $\begin{array}{l}\text { 4. I have established time limits for } \\
\text { work tasks. }\end{array}$ & 4.170 & 0.872 & 0.755 & 21.602 & 0.000 \\
\cline { 2 - 7 } & 5. I prevent interruptions. & 4.090 & 0.861 & 0.355 & 4.276 & 0.000 \\
\hline
\end{tabular}

\section{Copyright Disclaimer}

Copyright for this article is retained by the author(s), with first publication rights granted to the journal.

This is an open-access article distributed under the terms and conditions of the Creative Commons Attribution license (http://creativecommons.org/licenses/by/3.0/). 